\title{
Fundamental Studies of Butane Oxidation over Model- Supported Vanadium Oxide Catalysts: Molecular Structure-Reactivity Relationships
}

\author{
I srael E. Wachs, ${ }^{*}$ J ih-M irn J ehng, ${ }^{*, 1}$ G outam D eo, ${ }^{*, 2}$ B ert M . Weckhuysen, ${ }^{*, 3}$ \\ V. V. Guliants, $\dagger^{4}$ J. B. B enziger, $\dagger$ and S. Sundaresan $\dagger$ \\ *Z ettlemoyer Center for Surface Studies, D epartment of Chemical E ngineering, L ehigh U niversity, B ethlehem, Pennsylvania 18015; \\ and $\nmid D$ epartment of Chemical E ngineering, P rinceton U niversity, P rinceton, N ew Jersey 08544 \\ R eceived J une 10, 1996; revised A pril 30, 1997; accepted M ay 5, 1997
}

The oxidation of $n$-butane to maleic anhydride was investigated over a series of model-supported vanadia catalysts where the vanadia phase was present as a two-dimensional metal oxide overlayer on the different oxide supports $\left(\mathrm{TiO}_{2}, \mathrm{ZrO}_{2}, \mathrm{CeO}_{2}, \mathrm{Nb}_{2} \mathrm{O}_{5}, \mathrm{Al}_{2} \mathrm{O}_{3}\right.$, and $\mathrm{SiO}_{2}$ ). $\mathrm{No}$ correlation was found between the properties of the terminal $\mathbf{V}=0$ bond and the butane oxidation turnover frequency (TOF) during in situ R aman spectroscopy study. Furthermore, neither the $n$-butane oxidation TOF nor maleic anhydride selectivity was related to the extent of reduction of the surface vanadia species. The $n$-butane oxidation TOF was essentially independent of the surface vanadia coverage, suggesting that the $n$-butane activation requires only one surface vanadia site. The maleic anhydride TOF, however, increased by a factor of 2-3 asthesurfacevanadia coverage was increased to monolayer coverage. The higher maleic anhydride TOF at near monolayer coverages suggests that a pair of adjacent vanadia sites may efficiently oxidize $n$-butane to maleic anhydride, but other factors may also play a contributing role (increase in surface Brønsted acidity and decrease in the number of exposed support cation sites). Varying the specific oxide support changed the $n$-butaneoxidation TOF by ca. $50(\mathrm{Ti}>\mathrm{Ce}>\mathrm{Zr} \sim \mathrm{N} \mathrm{b}>\mathrm{Al}>\mathrm{Si})$ as well as the maleic anhydride selectivity. The maleic anhydride selectivity closely followed the Lewis acid strength of the oxide support cations, $\mathrm{Al}>\mathrm{Nb}>\mathrm{Ti}>\mathrm{Si}>\mathrm{Zr}>\mathrm{Ce}$. The addition of acidic surface metal oxides ( $W, N b$, and $P$ ) to the surface vanadia layer was found to have a beneficial effect on the $n$-butane oxidation TOF and the maleic anhydride selectivity. The creation of bridging V-O-P bonds had an especially positive effect on the maleic anhydride selectivity. (c) 1997 Academic Press

\footnotetext{
${ }^{1}$ Current address: D epartment of Chemical Engineering, $N$ ational Chung-H sing U niversity, Taichung 402, Taiwan, R.O.C.

${ }^{2}$ C urrent address: D epartment of Chemical E ngineering, Indian Institute of Technology, K anpur, 208 016, India.

${ }^{3}$ Current address: Centrum voor Oppervlaktechemie en $\mathrm{K}$ atalyse, K. U. L euven, K ardinaal M ercierlaan 92, B-3001 H everlee, B elgium.

${ }^{4}$ Current address: Praxair, Inc., 175 East Park Drive, P.O. B ox 44, Tonawanda, NY 14151.
}

\section{INTRODUCTION}

Oxidation of n-butane to maleic anhydride over the heterogeneous vanadium-phosphorus-oxide (V PO) catalysts is currently the only industrial catalytic process for partial oxidation of an alkane. Crystalline vanadyl(IV) pyrophosphate, ( $\mathrm{VO})_{2} \mathrm{P}_{2} \mathrm{O}_{7}$, is present in the most selective catalysts. However, various vanadium phosphates have been detected in the V PO catalysts depending on the methods of preparation and conditioning of the conventional catalyst precursor, vanadyl(IV) hydrogen phosphate hemihydrate. A s a result, the current literature demonstrates the lack of agreement on the nature of the active phase (1). Various models of active sites in n-butane oxidation to maleic anhydride have been proposed to date: (i) coherent interfaces between various $\mathrm{VO} \mathrm{PO}_{4}$ phases and $(\mathrm{VO})_{2} \mathrm{P}_{2} \mathrm{O}_{7}$ (2), (ii) a mixture of well-crystallized ( $\mathrm{VO})_{2} \mathrm{P}_{2} \mathrm{O}_{7}$ and an amorphous $\mathrm{VOPO}_{4}$ phase involving corner-sharing octahedra $(3,4)$, (iii) $\mathrm{V}^{5+}$ species in strong interaction with the $\mathrm{VO}\left(\mathrm{PO}_{3}\right)_{2}$ structure in the V PO catalysts (5), and (iv) the presence of $\mathrm{V}^{5+}$ sites on the (200) planes of $(\mathrm{VO})_{2} \mathrm{P}_{2} \mathrm{O}_{7}(6)$.

In many experimental studies, the limitations of the currently available bulk and surface characterization techniques have been coupled with the complex solid-state chemistry of vanadium phosphate. A sa result, considerable confusion and contradictions exist in the literature concerning the identity of the active sites involved in different steps of the catalytic reaction ( $1 a, 6,7)$. Experimental results support the conclusions that the best V PO catalysts preferentially expose the (200) planes of $(\mathrm{VO})_{2} \mathrm{P}_{2} \mathrm{O}_{7}$ and that the bulk vanadyl pyrophosphate serves as a support for this active surface ( $1 a, 6-8)$. The recent models for n-butane oxidation are based on the presence of vanadyl dimers in the (200) plane of vanadyl pyrophosphate $(6,9,10)$. The following types of hypothetical active sites have been proposed to exist on the surface (200) plane (8): (i) Brønsted acid sites: probably -POH groups; (ii) Lewis acid sites: 
probably $\mathrm{V}^{\mathrm{IV}}$ and $\mathrm{V}^{\mathrm{V}}$; (iii) one electron redox couple: $\mathrm{V}^{\mathrm{IV}} / \mathrm{V}^{\mathrm{V}}, \mathrm{V}^{\mathrm{III}} / \mathrm{N}^{\mathrm{IV}}$; (iv) two electron redox couple: $\mathrm{V}^{\mathrm{III}} \mathrm{N}^{\mathrm{V}}$; (v) bridging oxygen: $\mathrm{V}-\mathrm{O}-\mathrm{V}, \mathrm{V}-\mathrm{O}-\mathrm{P}$, or $\mathrm{VO}(\mathrm{P}) \mathrm{V}$; (vi) terminal oxygen: $\mathrm{V}^{\mathrm{V}}=0, \mathrm{~V}^{\mathrm{IV}}=0$; and (vii) activated molecular oxygen: peroxo and superoxo species. A ccording to a recent model (9) the vanadyl dimers from clusters on the surface (200) planes, each composed of four vanadyl dimers, which are isolated from other clusters by terminal pyrophosphate groups. This so-called site isolation in V PO catalysts, which requires only the local ordering in surface structure for the selectivity as well as the inertness of the bulk of the catalyst in n-butane oxidation (11), is analogous to supported metal oxide catalysts (12). In order to investigate the analogy between the bulk VPO and supported metal oxide catalysts we have performed a kinetic and physicochemical study of model supported vanadia catalysts in the n-butane oxidation. Such a study is particularly valuable, as unlike the bulk V PO catalysts, detailed surface structural information on a molecular level can be obtained from model-supported vanadium oxide catalysts containing two-dimentional vanadium oxide overlayers (13).

Several earlier studies of alkane oxidation, including that of n-butane, have been reported in the literature (14-17). $O$ wens and Kung (14) studied n-butane dehydrogenation on silica-supported vanadia catalysts. They employed an oxygen-lean feed gas $\left(\mathrm{O}_{2} /\right.$ butane ratio of $\left.2: 1\right)$ and a high reaction temperature (773-813 K) which resulted in preferential formation of dehydrogenation products, such as butenes, and only traces of maleic anhydride were detected. Mori et al. (15) studied oxidation of n-butane on titania-supported vanadia catalysts at very high temperatures $(\sim 773 \mathrm{~K})$ and high n-butane conversion. Such severe experimental conditions led to an overoxidation of n-butane to carbon oxides and, likely, to combustion of the partial oxidation products, including maleic anhydride. B usca et al. (16) employed titania-supported vanadia catalysts in n-butane oxidation and observed overoxidation of the hydrocarbon on very active high surface area catalyst $\left(117 \mathrm{~m}^{2} / \mathrm{g}\right.$ ) at $\sim 723 \mathrm{~K}$. When B usca et al. supported $10 \mathrm{wt} . \%$ $\mathrm{V}_{2} \mathrm{O}_{5}$ on the low surface area titania $\left(17 \mathrm{~m}^{2} / \mathrm{g}\right)$, vanadia formed microcrystals which were detrimental to selective oxidation and led to n-butane combustion. A number of studies of supported V PO catalysts have been described in the literature (17). N akamura et al. (17a) studied oxidation of 1-butene on alumina-supported catalysts and reported reasonably high selectivities to maleic anhydride. The results of their study (17a) showed that supported V PO catalysts can selectively oxidize $C 4$ hydrocarbons to maleic anhydride. Zazhigalov et al. (17b) immobilized the V PO component by adsorption of $\mathrm{V}(\mathrm{V})$ and $\mathrm{P}(\mathrm{V})$ sources onto the silanol groups of silica support in nonaqueous medium. The formation of the amorphous V PO clusters improved selectivity to maleic anhydride. The n-butane conversion and selectivity to maleic anhydride depended on the P/V ra- tio employed during synthesis, which the authors related to the changes in acidity (17b). The studies of others on silica-, titania-, alumina-, and A IPO 4 -supported catalysts (17c-g) demonstrated further that the activity of supported catalysts depends on the nature of the support used and that the selectivity to maleic anhydride is affected by the average valence state of vanadium. O verbeek (18) studied $n$ butane oxidation to maleic anhydride on titania-supported V PO catalysts. The catalysts showed reasonable activity and selectivity in n-butane oxidation at temperatures $\sim 100 \mathrm{~K}$ lower than commercial catalysts. O verbeek concluded that the activity of titania-supported V PO catalysts was related to their reducibility based on the results of the temperature programmed reduction experiments, as well as to the average oxidation state of vanadium ions on the surface (18). Haber et al. (19) have recently studied oxidation of n-butane to maleic anhydride on the VPO catalysts containing different concentrations of alkali and alkali earth metal ion promoters. They found that the promoters affected the basicity of surface oxygen atoms and that the rate of n-butane activation was proportional to the basicity of surface oxygen. On the other hand, selectivity to maleic anhydride correlated with the concentration of the acidic sites on the surface, passing through a maximum as the concentration of acid sites increased. $\mathrm{H}$ aber et al. (19) believe that the surface acidic sites affect selectivity by controlling adsorption of reaction intermediates with acidic properties.

Unlike the present study, the previous studies (14-19) were largely conducted on poorly characterized vanadia and VPO catalysts, where it was difficult to establish the relationship between the catalytic behavior and structure. In previous studies, the experimental conditions were also frequently unfavorable for selective n-butane oxidation (e.g., very high reaction temperature, high butane conversion, oxygen-lean environment). The present study employs well-defined model supported vanadium oxide catalysts, oxygen-18 labeling, and in situ R aman characterization during butane oxidation to provide structure reactivity relationships for this catalytic system.

\section{EXPERIMENTAL}

\section{a. M aterials and Preparation}

Supported vanadium oxide catalysts on $\mathrm{TiO}_{2}$ ( $\mathrm{D}$ egussa, $\sim 55 \mathrm{~m}^{2} / \mathrm{g}$ ), $\mathrm{ZrO}_{2}$ (D egussa, $\sim 39 \mathrm{~m}^{2} / \mathrm{g}$ ), $\mathrm{Nb}_{2} \mathrm{O}_{5}$ (N iobium Products Company, $\left.\sim 55 \mathrm{~m}^{2} / \mathrm{g}\right), \mathrm{CeO}_{2}\left(\sim 36 \mathrm{~m}^{2} / \mathrm{g}\right), \mathrm{Al}_{2} \mathrm{O}_{3}$ ( $\mathrm{H}$ arshaw, $\sim 180 \mathrm{~m}^{2} / \mathrm{g}$ ), and $\mathrm{SiO}_{2}$ (Cab-O-Sil, EH 5, 380 $\mathrm{m}^{2} / \mathrm{g}$ ) were prepared by the incipient-wetness impregnation method. A vanadium isopropoxide (A Ifa, 95-99\% purity) in a methanol solution (Fisher, $99.9 \%$ purity) was used to impregnate the oxide support under a nitrogen environment. The samples were initially dried at room temperature for $2 \mathrm{hr}$ to remove excess methanol and further dried at $393 \mathrm{~K}$ for $16 \mathrm{hr}$ under flowing $\mathrm{N}_{2}$. The samples were finally 
calcined at $773 \mathrm{~K}$ for $1 \mathrm{hr}$ under flowing $\mathrm{N}_{2}$; an additional $1 \mathrm{hr}$ under flowing dry air for the $\mathrm{TiO}_{2}, \mathrm{ZrO}_{2}, \mathrm{Nb}_{2} \mathrm{O}_{5}$, and $\mathrm{CeO}_{2}$ supports; and an additional $15 \mathrm{hr}$ under flowing dry air for the $\mathrm{Al}_{2} \mathrm{O}_{3}$ and $\mathrm{SiO}_{2}$ supports to form the surface vanadium oxide species on oxide supports. A mmonium metatungstate (Pfaltz \& Bauer, 99.9\% purity) in aqueous solution was used to impregnate the $1 \% \mathrm{~V}_{2} \mathrm{O}_{5} / \mathrm{TiO}_{2}$ sample (20), and the same drying-and-calcining procedure as above was followed to prepare the $6 \% \mathrm{WO}_{3} / 1 \% \mathrm{~V}_{2} \mathrm{O}_{5} / \mathrm{TiO} 2$ sample. A diluted phosphoric acid (A Idrich, $85 \%$ in water) solution was preimpregnated on the $\mathrm{TiO}_{2}$ support and used as a support for the preparation of the $1 \% \mathrm{~V}_{2} \mathrm{O}_{5} / 5 \% \mathrm{P}_{2} \mathrm{O}_{5} / \mathrm{TiO}_{2}$ sample (21).

\section{b. Raman Spectroscopy}

In situ Raman spectroscopy. The in situ Raman spectrometer system consists of a quartz cell and a sample holder, a triple-grating spectrometer (Spex, M odel 1877), a photodiode array detector ( $E G \& G$, Princeton A pplied R esearch, Model 1420), and an argon ion laser (SpectraPhysics, Model 165). The sample holder is made from a metal alloy (Hastalloy C), and a 100- to 200-mg sample disc is held by the cap of the sample holder. The sample holder is mounted onto a ceramic shaft which is rotated by a 115 V D C motor at a speed of 1000-2000 rpm. A cylindrical heating coil surrounding the quartz cell is used to heat the sample and the temperature is measured by an internal thermocouple. The quartz cell is capable of operating up to $873 \mathrm{~K}$, and flowing gas is introduced into the cell at a rate of $50-300 \mathrm{~cm}^{3} / \mathrm{min}$ at atmospheric pressure. The $514.5-\mathrm{nm}$ line of the $\mathrm{A} \mathrm{r}^{+}$laser with $10-100 \mathrm{~mW}$ of power is focused on the sample disc in a right-angle scattering geometry. A n ellipsoid mirror collects and reflects the scattered light into the spectrometer's filter stage to reject the elastic scattering component. The resulting filtered light, consisting primarily of the Raman component of the scattered light, is collected with an $E G \& G$ intensified photodio de array detector which is coupled to the spectrometer and is thermoelectrically cooled to $-238 \mathrm{~K}$. The photodiode array detector is scanned with an E G \& G O M A III optical multichannel analyzer (Model 1463).

The in situ R aman spectra were obtained employing the following procedure. The samples were placed into the cell and heated to $773 \mathrm{~K}$ for $1 \mathrm{hr}$ in a flow of pure oxygen gas (L inde Specialty Grade, $99.99 \%$ purity). The dehydrated $\mathrm{R}$ aman spectra were collected after the sample was cooled to $503 \mathrm{~K}$ in a flow of pure oxygen gas for $30 \mathrm{~min}$. A fter the above treatment, a $1 / 4$ ratio of oxygen and a gaseous mixture $1.49 \% \quad \mathrm{C}_{4} \mathrm{H}_{10} / \mathrm{H}$ e with a flow rate of $100 \mathrm{~cm}^{3} / \mathrm{min}$ was introduced into the cell, and the R aman spectra under reaction conditions were collected after reaching steady state ( $\sim 30 \mathrm{~min}$ at the $503 \mathrm{~K}$ reaction temperature). R aman spectra were also recorded at higher reaction temperatures of 573 and $623 \mathrm{~K}$. A t the $623 \mathrm{~K}$ reaction temperature, the
R aman spectra were also recorded by decreasing of the reactant gas flow rate from 100 to $50 \mathrm{~cm}^{3} / \mathrm{min}$. The catalysts were subsequently reoxidized by flowing pure oxygen at $623 \mathrm{~K}$ for $1 \mathrm{hr}$.

The reactor aspects of the in situ $\mathrm{R}$ aman cell were also determined with an on-line mass spectrometer and different sample quantities. For the $4 \% \mathrm{~V}_{2} \mathrm{O}_{5} / \mathrm{Z} \mathrm{rO}_{2}$ catalyst, the conversion of butane was less than $1 \%$ at $503 \mathrm{~K}$ and ca. $3 \%$ at $573 \mathrm{~K}$. The low conversions are due to bypassing of the catalyst by the gaseous reactants and the presence of strong mass transfer limitations in the pressed catalyst pellet. Consequently, only the exterior region of the catalyst pellet participated in butane oxidation. Fortunately, for such colored and dark samples the R aman signal primarily originates from the sample exterior. Thus, the R aman signal originates from the reaction zone.

\section{c. K inetic Tests}

D uring kinetic tests, ca. $1 \mathrm{~g}$ of catalyst wasplaced into a $\mathrm{U}$ tube Pyrex glass reactor inside an al uminum split block. The reactor was heated in the $1.2 \% \mathrm{n}$-butane flow at $20 \mathrm{~cm}^{3} / \mathrm{min}$ to $494 \mathrm{~K}$, after which the kinetic data were collected for up to $120 \mathrm{hr}$ under the catalytic reaction conditions. A II experiments were carried out in once-through integral mode. The reaction was run under conditions where diffusional limitations could be neglected. CP grade n-butane from $M$ atheson and dry house air were metered separately using $B$ rooks M odel 52-36A $1 \mathrm{~V}$ Series mass flow controllers with M odel 5876 two-channel power supply box and were mixed in desired proportions. O nly a small fraction of the total flow was metered to the reactor, with the rest being vented.

The effluent stream was analyzed by on-line gas chromatography. A side stream ran from the heated effluent line to a H P 5790A Series gas chromatograph (GC), where partial oxidation products (mainly M A and traces of acetic and acrylic acids) were separated on a 2-m-long Porapak Q S column. A fter the partial oxidation products were stripped from the effluent by passing through a water bubbler, the effluent samples from a sample loop were injected into two G C columns in series: a 5-m-long $30 \%$ bis-2-ethoxyethyl sebacate column to separate $\mathrm{CO}_{2}$ and butane, and a 4-m-long molecular sieve $13 \mathrm{X}$ column to separate $\mathrm{O}_{2}, \mathrm{~N}_{2}$, and $\mathrm{CO}$. The lines running from the reactor to the H P 5790A gas chromatograph and the water bubbler were kept at $423 \mathrm{~K}$ to prevent condensation of maleic anhydride. Calibration for maleic anhydride was achieved by periodic acid-base titrations of the bubbler solution using a phenolphthalein indicator. The bubbler solution was sampled after passing the effluent through the deionized water in the bubbler at a constant space velocity for $1 \mathrm{hr}$. Concentrations of carbon oxides, butane, nitrogen, and oxygen in the effluent were determined using the calibration gas mixture ( $A$ irco) containing certified concentrations of the above gases. Closure on the overall carbon balances was $\pm 5 \%$. 


\section{RESULTS}

In Situ Raman Spectra during B utane 0 xidation

$7 \% \mathrm{~V}_{2} \mathrm{O}_{5} / \mathrm{SiO}_{2}$. The in situ $\mathrm{R}$ aman spectra of the $7 \%$ $\mathrm{V}_{2} \mathrm{O}_{5} / \mathrm{SiO}_{2}$ catalyst at various stages of the butane oxidation reaction are shown in Fig. 1. Prior to reaction, a sharp and strong R aman band is present at $1038 \mathrm{~cm}^{-1}$ which is characteristic of the terminal $\mathrm{V}=0$ bond of the dehydrated surface vanadium oxide species (22). The $7 \% \quad \mathrm{~V}_{2} \mathrm{O}_{5} / \mathrm{SiO}_{2}$ catalyst corresponds to approximately a quarter monolayer coverage of the two-dimentional surface vanadate overlayer. M onolayer coverages of metal oxides on $\mathrm{SiO}_{2}$ are not achievable because of the weak interaction of oxides with the silica surface (12a). D uring butane oxidation, the $R$ aman features of the surface vanadium oxide species are not affected by the reaction environment. The R aman intensities of silanol groups ( $R$ aman band at $\sim 977 \mathrm{~cm}^{-1}$ ) decrease slightly during butane oxidation, which indicates adsorption of some hydrocarbons on the $\mathrm{SiO}_{2}$ surface. $\mathrm{R}$ aman features of adsorbed hydrocarbon functionalities in the $2000-3000 \mathrm{~cm}^{-1}$ region, however, could not be detected during butane oxidation. $\mathrm{No}$ crystalline $\mathrm{V}_{2} \mathrm{O}_{5}$ ( $\mathrm{R}$ aman bands at $\sim 994, \sim 702, \sim 527, \sim 404, \sim 284$, and $\sim 146 \mathrm{~cm}^{-1}$ ) was present in this series of experiments.

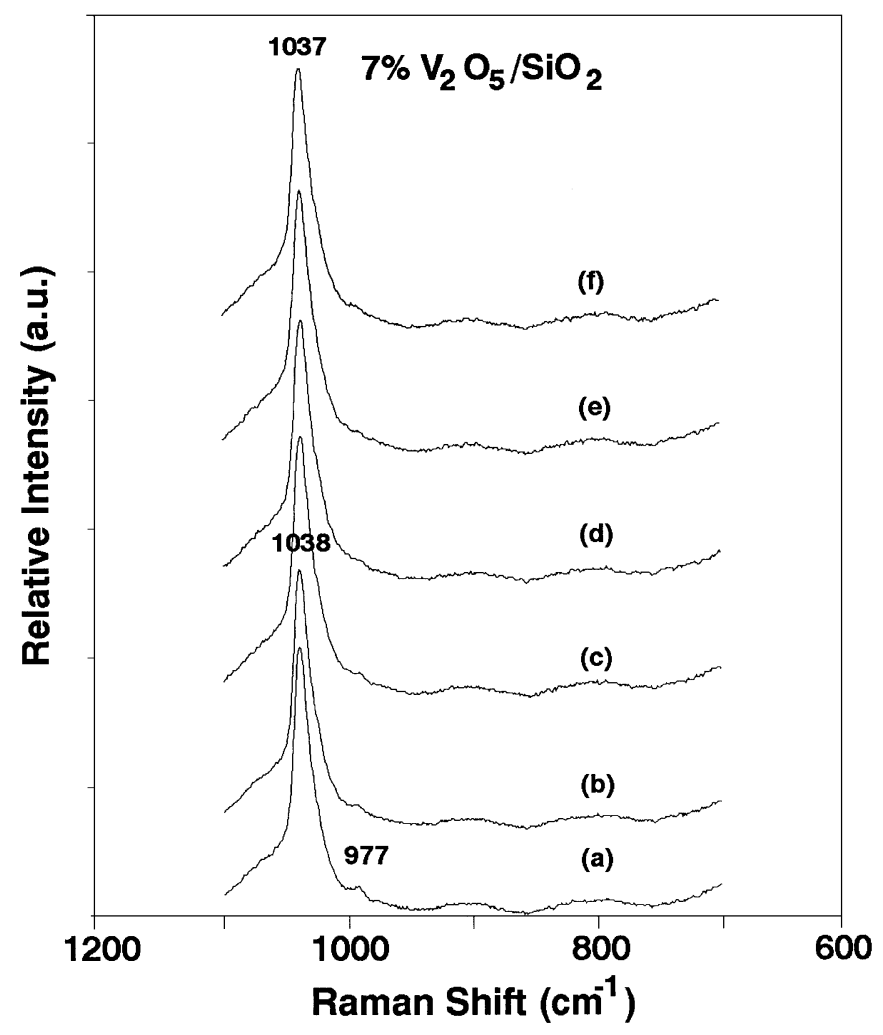

FIG. 1. In situ R aman spectra of the $7 \% \mathrm{~V}_{2} \mathrm{O}_{5} / \mathrm{SiO}_{2}$ catalyst during $\mathrm{n}$ butane oxidation. (a) $\mathrm{O}_{2}, 100 \mathrm{~cm}^{3} / \mathrm{min}, 503 \mathrm{~K}$; (b) $\mathrm{C}_{4} \mathrm{H}_{10} / \mathrm{O}_{2} / \mathrm{H} \mathrm{e}, 100 \mathrm{~cm}^{3} /$ $\min , 503 \mathrm{~K}$; (c) $\mathrm{C}_{4} \mathrm{H}_{10} / \mathrm{O}_{2} / \mathrm{He}, 100 \mathrm{~cm}^{3} / \mathrm{min}, 573 \mathrm{~K}$; (d) $\mathrm{C}_{4} \mathrm{H}_{10} / \mathrm{O}_{2} / \mathrm{He}$, $100 \mathrm{~cm}^{3} / \mathrm{min}, 623 \mathrm{~K}$; (e) $\mathrm{C}_{4} \mathrm{H}_{10} / \mathrm{O}_{2} / \mathrm{He}, 50 \mathrm{~cm}^{3} / \mathrm{min}, 623 \mathrm{~K}$; (f) $\mathrm{O}_{2}, 623 \mathrm{~K}$.

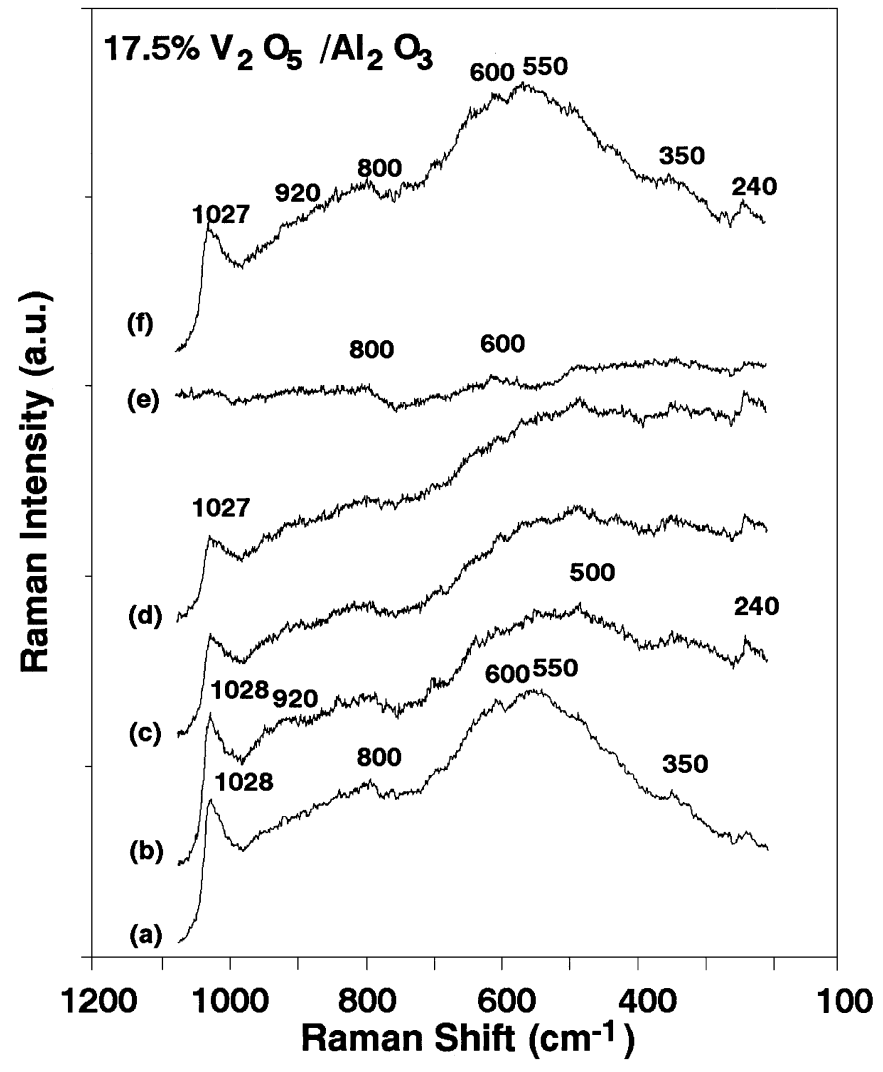

FIG. 2. In situ $\mathrm{R}$ aman spectra of the $17.5 \% \mathrm{~V}_{2} \mathrm{O}_{5} / \mathrm{Al}_{2} \mathrm{O}_{3}$ catalyst during n-butane oxidation. (a) $\mathrm{O}_{2}, 100 \mathrm{~cm}^{3} / \mathrm{min}, 503 \mathrm{~K}$; (b) $\mathrm{C}_{4} \mathrm{H}_{10} / \mathrm{O}_{2} / \mathrm{He}$, $100 \mathrm{~cm}^{3} / \mathrm{min}, 503 \mathrm{~K}$; (c) $\mathrm{C}_{4} \mathrm{H}_{10} / \mathrm{O}_{2} / \mathrm{He}, 100 \mathrm{~cm}^{3} / \mathrm{min}, 573 \mathrm{~K}$; (d) $\mathrm{C}_{4} \mathrm{H}_{10} / \mathrm{O}_{2} / \mathrm{He}, 100 \mathrm{~cm}^{3} / \mathrm{min}, 623 \mathrm{~K}$; (e) $\mathrm{C}_{4} \mathrm{H}_{10} / \mathrm{O}_{2} / \mathrm{H} \mathrm{e}, 50 \mathrm{~cm}^{3} / \mathrm{min}, 623 \mathrm{~K}$; (f) $\mathrm{O}_{2}, 623 \mathrm{~K}$.

$17.5 \% \mathrm{~V}_{2} \mathrm{O}_{5} / \mathrm{Al}_{2} \mathrm{O}_{3}$. The in situ $\mathrm{R}$ aman spectra of the $17.5 \% \mathrm{~V}_{2} \mathrm{O}_{5} / \mathrm{Al}_{2} \mathrm{O}_{3}$ catalyst during butane oxidation are shown in Fig. 2. Monolayer coverage of surface vanadia species on $\mathrm{A} \mathrm{I}_{2} \mathrm{O}_{3}$ corresponds to $\sim 20 \% \quad \mathrm{~V}_{2} \mathrm{O}_{5} / \mathrm{Al}_{2} \mathrm{O}_{3}$. $B$ oth dehydrated terminal $\mathrm{V}=0$ bonds ( $\mathrm{R}$ aman band at $\sim 1028 \mathrm{~cm}^{-1}$ ) and surface polyvanadate functionalities ( $R$ aman band at $\sim 920, \sim 800, \sim 600, \sim 550, \sim 350$, and $\sim 240$ $\mathrm{cm}^{-1}$ ) are present on the alumina surface. D uring butane oxidation, the R aman intensities of these two surface vanadium oxide functionalities simultaneously decrease. The surface polyvanadate functionality is more extensively reduced than the terminal $\mathrm{V}=0$ bond, which is manifested in the dramatically decreased $R$ aman band at $\sim 550 \mathrm{~cm}^{-1}$ characteristic of the bending mode of the bridging $\mathrm{V}-\mathrm{O}-\mathrm{V}$ bond. The R aman intensities of these two surface vanadia functionalities further decrease at higher reaction temperatures. $\mathrm{R}$ aman features of the surface vanadium oxide species on alumina disappear with the absence of oxygen at $623 \mathrm{~K}$. The initial dehydrated $R$ aman features of the surface vanadia species on alumina are obtained after reoxidation of the catalyst at $623 \mathrm{~K}$ under flowing oxygen. $\mathrm{No}$ crystalline $\mathrm{V}_{2} \mathrm{O}_{5}$ $\mathrm{R}$ aman features were detected in this series of experiments. 


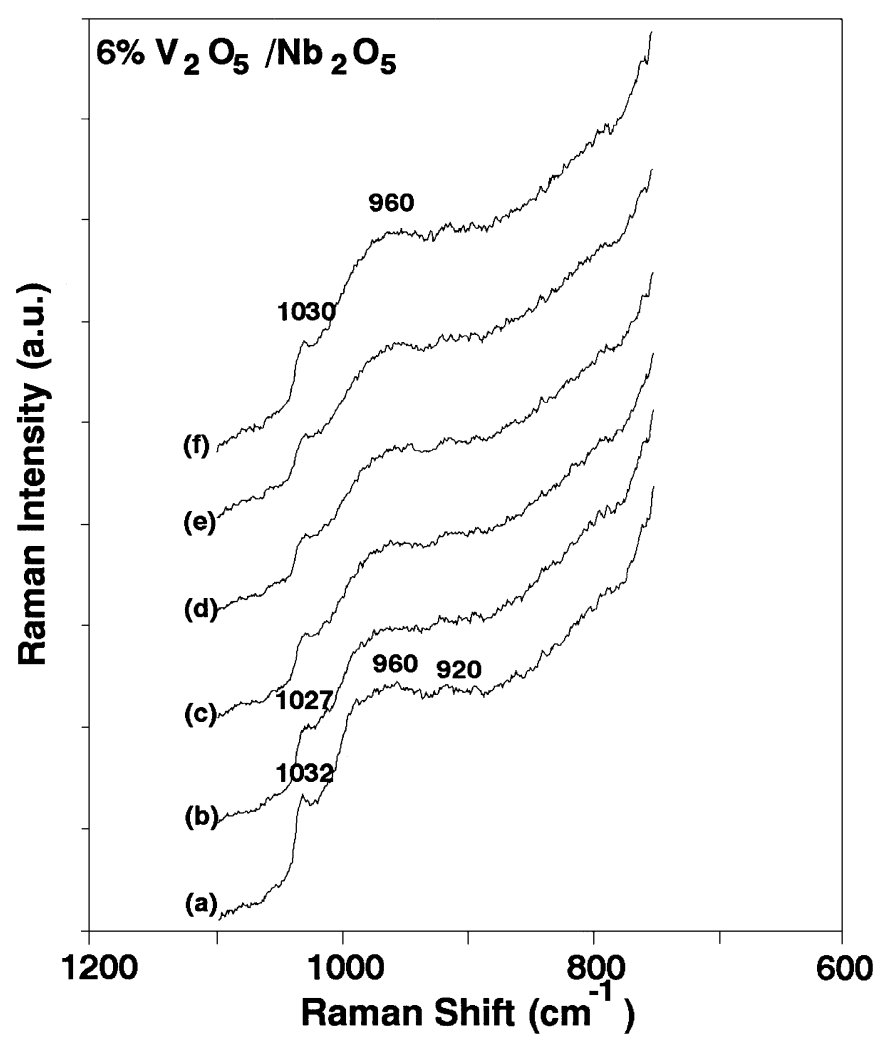

FIG. 3. In situ $\mathrm{R}$ aman spectra of the $6 \% \mathrm{~V}_{2} \mathrm{O}_{5} / \mathrm{Nb}_{2} \mathrm{O}_{5}$ catalyst during n-butane oxidation. (a) $\mathrm{O}_{2}, 100 \mathrm{~cm}^{3} / \mathrm{min}, 503 \mathrm{~K}$; (b) $\mathrm{C}_{4} \mathrm{H}_{10} / \mathrm{O}_{2} / \mathrm{H} \mathrm{e}, 100 \mathrm{~cm}^{3} /$ $\min , 503 \mathrm{~K}$; (c) $\mathrm{C}_{4} \mathrm{H}_{10} / \mathrm{O}_{2} / \mathrm{H} \mathrm{e}, 100 \mathrm{~cm}^{3} / \mathrm{min}, 573 \mathrm{~K}$; (d) $\mathrm{C}_{4} \mathrm{H}_{10} / \mathrm{O}_{2} / \mathrm{He}, 100$ $\mathrm{cm}^{3} / \mathrm{min}, 623 \mathrm{~K}$; (e) $\mathrm{C}_{4} \mathrm{H}_{10} / \mathrm{O}_{2} / \mathrm{H} \mathrm{e}, 50 \mathrm{~cm}^{3} / \mathrm{min}, 623 \mathrm{~K}$; (f) $\mathrm{O}_{2}, 623 \mathrm{~K}$.

$6 \% \mathrm{~V}_{2} \mathrm{O}_{5} / \mathrm{Nb}_{2} \mathrm{O}_{5}$. The in situ $\mathrm{R}$ aman spectra of the $6 \%$ $\mathrm{V}_{2} \mathrm{O}_{5} / \mathrm{N} \mathrm{b}_{2} \mathrm{O}_{5}$ catalyst during butane oxidation are presented in Fig. 3. M onolayer coverage of surface vanadia species on $\mathrm{Nb}_{2} \mathrm{O}_{5}$ corresponds to $\sim 7 \% \mathrm{~V}_{2} \mathrm{O}_{5} / \mathrm{Nb}_{2} \mathrm{O}_{5}$ (21). A sharp and weak $\mathrm{R}$ aman band is present at $\sim 1032 \mathrm{~cm}^{-1}$, characteristic of the terminal $\mathrm{V}=0$ bond of the dehydrated surface vanadium oxide species. A broad R aman band at $\sim 960 \mathrm{~cm}^{-1}$, characteristic of the polymeric surface vanadate functionalities on the niobia surface, is also present. D uring butane oxidation, the $\mathrm{R}$ aman intensities of these two surface vanadium oxide functionalities decrease somewhat. No crystalline $\mathrm{V}_{2} \mathrm{O}_{5} \mathrm{R}$ aman features were present in this series of experiments.

$4 \% \mathrm{~V}_{2} \mathrm{O}_{5} / \mathrm{ZrO}_{2}$. The in situ $\mathrm{R}$ aman spectra of the $4 \%$ $\mathrm{V}_{2} \mathrm{O}_{5} / \mathrm{ZrO}_{2}$ catalyst during butane oxidation are shown in Fig. 4. M onolayer coverage of the surface vanadia species on $\mathrm{ZrO}_{2}$ corresponds to $\sim 4 \% \mathrm{~V}_{2} \mathrm{O}_{5} / \mathrm{ZrO}_{2}$ (21). Both dehydrated surface terminal $V=0$ groups ( $R$ aman band at $\sim 1032 \mathrm{~cm}^{-1}$ ) and surface polymeric vanadate functionalities are present on the $\mathrm{ZrO}_{2}$ surface. $A$ trace of crystalline $\mathrm{V}_{2} \mathrm{O}_{5}$ ( $\mathrm{R}$ aman band at $\sim 992 \mathrm{~cm}^{-1}$ ) is also present on the $\mathrm{ZrO}_{2}$ surface. D uring butane oxidation, the $\mathrm{R}$ aman intensities of the terminal $V=0$ and polymeric vanadate functionalities decrease somewhat due to the reduction of the surface vanadium oxide species. The crystalline $\mathrm{V}_{2} \mathrm{O}_{5}$ phase is not affected by the butane oxidation environment.

$3 \% \mathrm{~V}_{2} \mathrm{O}_{5} / \mathrm{CeO}_{2}$. The in situ $\mathrm{R}$ aman spectra of the $3 \%$ $\mathrm{V}_{2} \mathrm{O}_{5} / \mathrm{CeO}_{2}$ catalyst during butane oxidation are shown in Fig. 5. M onolayer coverage of surface vanadia species on $\mathrm{CeO}_{2}$ corresponds to $\sim 4 \% \mathrm{~V}_{2} \mathrm{O}_{5} / \mathrm{CeO}_{2}$ (23). D ehydrated surface vanadium oxide species with the terminal $\mathrm{V}=0$ ( $R$ aman band at $\sim 1027 \mathrm{~cm}^{-1}$ ) and surface polymeric vanadate functionalities ( $R$ aman band at $\sim 920 \mathrm{~cm}^{-1}$ ) coexist on the ceria surface. D uring butane oxidation, the R aman intensities of these two surface vanadium oxide functionalities ( 1027 and $\sim 920 \mathrm{~cm}^{-1}$ ) decrease slightly. N o crystalline $\mathrm{V}_{2} \mathrm{O}_{5} \mathrm{R}$ aman features were found in this series of experiments.

$1 \% \mathrm{~V}_{2} \mathrm{O}_{5} / \mathrm{TiO}_{2}$. The in situ Raman spectra of the $1 \% \mathrm{~V}_{2} \mathrm{O}_{5} / \mathrm{TiO}_{2}$ catalyst during butane oxidation are presented in Fig. 6. M onolayer coverage of vanadia on titania corresponds to $\sim 6 \% \mathrm{~V}_{2} \mathrm{O}_{5} / \mathrm{TiO}_{2}$ (21). A sharp and strong $\mathrm{R}$ aman band is present at $1026 \mathrm{~cm}^{-1}$, characteristic of the terminal $V=0$ group of the dehydrated surface vanadium oxide species (20). D uring butane oxidation, the $R$ aman intensity of the surface vanadium oxide species $\left(\sim 1026 \mathrm{~cm}^{-1}\right)$ decreases somewhat at $503 \mathrm{~K}$. A t higher reaction temperatures ( 573 and $623 \mathrm{~K}$ ), the increased R aman intensity of the

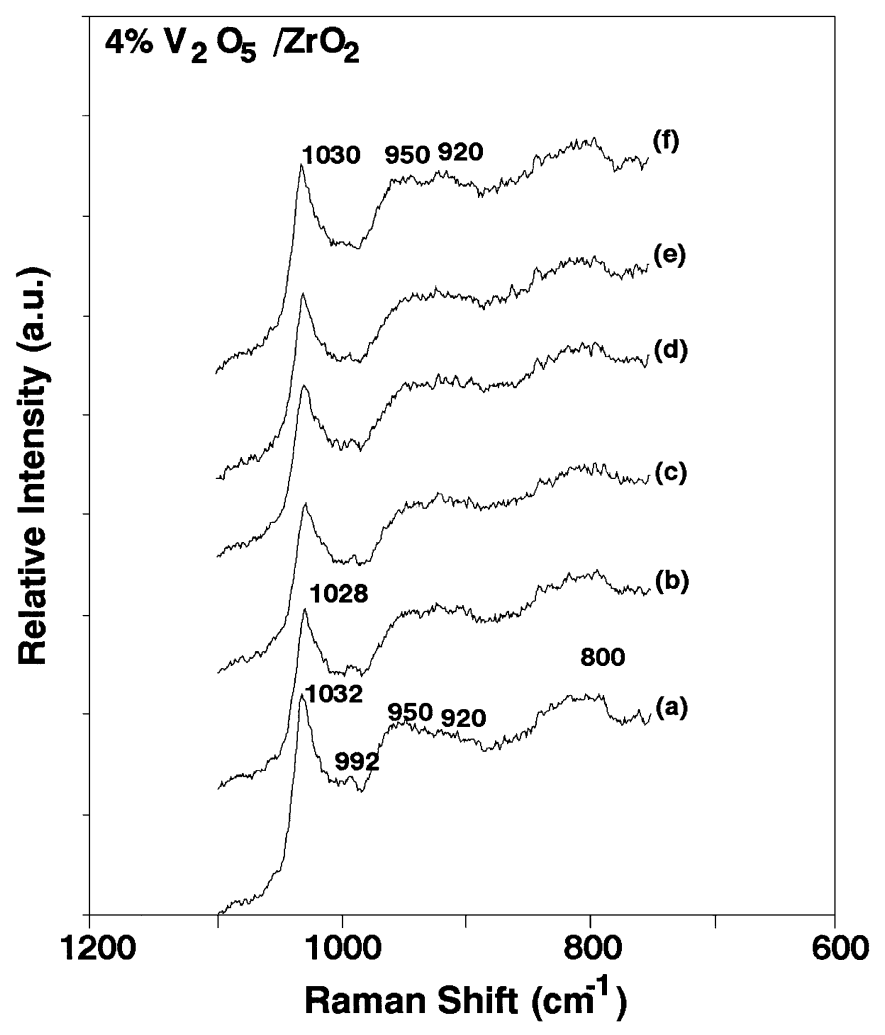

FIG . 4. In situ $\mathrm{R}$ aman spectra of the $4 \% \mathrm{~V}_{2} \mathrm{O}_{5} / \mathrm{ZrO}_{2}$ catalyst during n-butane oxidation. (a) $\mathrm{O}_{2}, 100 \mathrm{~cm}^{3} / \mathrm{min}, 503 \mathrm{~K}$; (b) $\mathrm{C}_{4} \mathrm{H}_{10} / \mathrm{O}_{2} / \mathrm{H} \mathrm{e}, 100 \mathrm{~cm}^{3} /$ $\min , 503 \mathrm{~K}$; (c) $\mathrm{C}_{4} \mathrm{H}_{10} / \mathrm{O}_{2} / \mathrm{H} \mathrm{e}, 100 \mathrm{~cm}^{3} / \mathrm{min}, 573 \mathrm{~K}$; (d) $\mathrm{C}_{4} \mathrm{H}_{10} / \mathrm{O}_{2} / \mathrm{H} \mathrm{e}, 100$ $\mathrm{cm}^{3} / \mathrm{min}, 623 \mathrm{~K}$; (e) $\mathrm{C}_{4} \mathrm{H}_{10} / \mathrm{O}_{2} / \mathrm{H} \mathrm{e}, 50 \mathrm{~cm}^{3} / \mathrm{min}, 623 \mathrm{~K}$; (f) $\mathrm{O}_{2}, 623 \mathrm{~K}$. 


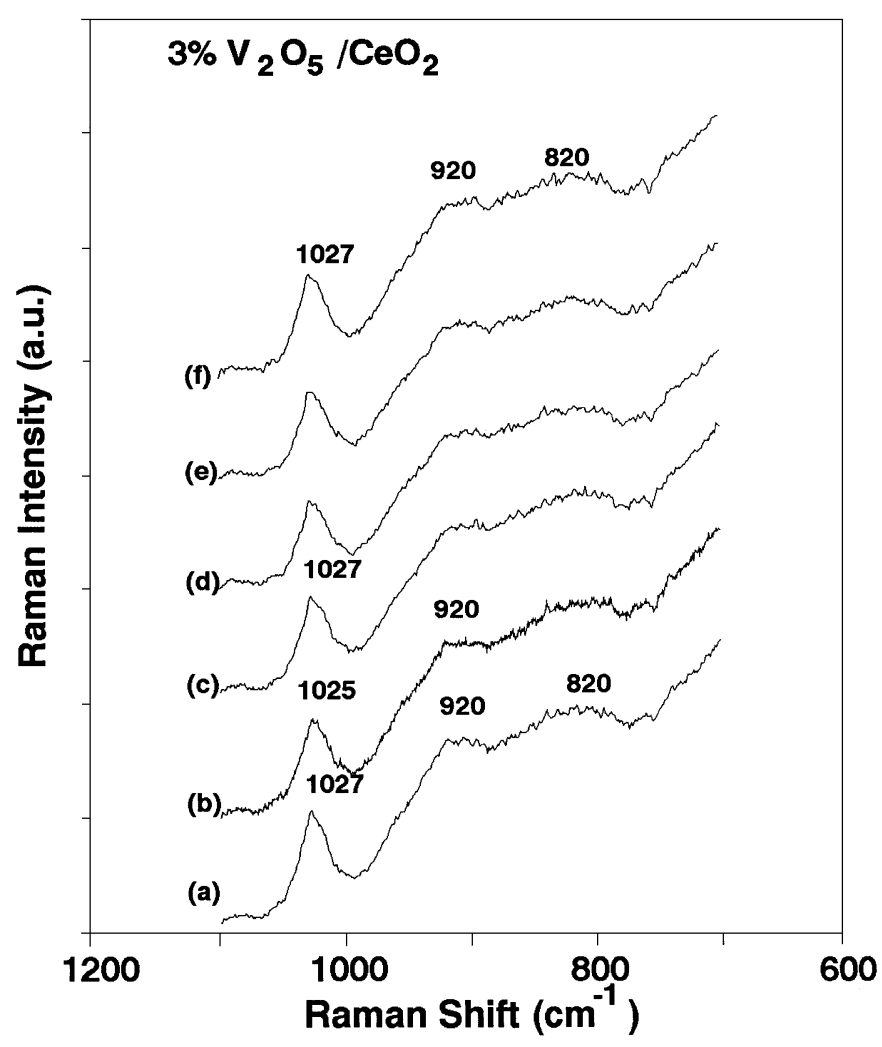

FIG. 5. In situ $\mathrm{R}$ aman spectra of the $3 \% \mathrm{~V}_{2} \mathrm{O}_{5} / \mathrm{CeO}_{2}$ catalyst during n-butane oxidation. (a) $\mathrm{O}_{2}, 100 \mathrm{~cm}^{3} / \mathrm{min}, 503 \mathrm{~K}$; (b) $\mathrm{C}_{4} \mathrm{H}_{10} / \mathrm{O}_{2} / \mathrm{H} \mathrm{e}, 100 \mathrm{~cm}^{3} /$ $\min , 503 \mathrm{~K}$; (c) $\mathrm{C}_{4} \mathrm{H}_{10} / \mathrm{O}_{2} / \mathrm{H} \mathrm{e}, 100 \mathrm{~cm}^{3} / \mathrm{min}, 573 \mathrm{~K}$; (d) $\mathrm{C}_{4} \mathrm{H}_{10} / \mathrm{O}_{2} / \mathrm{H} \mathrm{e}, 100$ $\mathrm{cm}^{3} / \mathrm{min}, 623 \mathrm{~K}$; (e) $\mathrm{C}_{4} \mathrm{H}_{10} / \mathrm{O}_{2} / \mathrm{H} \mathrm{e}, 50 \mathrm{~cm}^{3} / \mathrm{min}, 623 \mathrm{~K}$; (f) $\mathrm{O}_{2}, 623 \mathrm{~K}$.

surface vanadium oxide species indicates that the presence of water at the lower reaction temperature is primarily responsible for the reduced R aman intensity at $503 \mathrm{~K}$ (24). There is no apparent reduction of the surface vanadium oxide species during butane oxidation at $623 \mathrm{~K}$ (compare Figs. 6e and 6f).

$5 \% \mathrm{~V}_{2} \mathrm{O}_{5} / \mathrm{TiO}_{2}$. The in situ Raman spectra of the $5 \% \mathrm{~V}_{2} \mathrm{O}_{5} / \mathrm{TiO}_{2}$ catalyst during butane oxidation are shown in Fig. 7. B oth dehydrated surface terminal $V=0$ groups (sharp R aman band at $\sim 1032 \mathrm{~cm}^{-1}$ ) and surface polyvanadate functionalities (broad R aman band at $\sim 940 \mathrm{~cm}^{-1}$ ) coexist on the titania surface. During butane oxidation, the Raman intensities of these two surface vanadium oxide functionalities ( $\sim 1032$ and $\sim 940 \mathrm{~cm}^{-1}$ ) decrease at all temperatures. $\mathrm{No}$ crystalline $\mathrm{V}_{2} \mathrm{O}_{5} \mathrm{R}$ aman features were present in this series of experiments. Thus, the surface vanadium oxide species are partially reduced during butane oxidation for the $5 \% \mathrm{~V}_{2} \mathrm{O}_{5} / \mathrm{TiO}_{2}$ catalyst.

$1 \% \mathrm{~V}_{2} \mathrm{O}_{5} / 5 \% \mathrm{P}_{2} \mathrm{O}_{5} / \mathrm{TiO}_{2}$. The in situ $\mathrm{R}$ aman spectra of the $1 \% \quad \mathrm{~V}_{2} \mathrm{O}_{5} / 5 \% \quad \mathrm{P}_{2} \mathrm{O}_{5} / \mathrm{TiO}_{2}$ catalyst during butane oxidation are presented in Fig. 8. The $\mathrm{R}$ aman band at $\sim 1034 \mathrm{~cm}^{-1}$ is characteristic of the dehydrated surface vanadate species. The broadening of this Raman band is due to the pres- ence of the surface phosphate species (weak R aman band at $\sim 1000 \mathrm{~cm}^{-1}$ ) on the titania surface. M onolayer coverage of surface phosphate species on $\mathrm{TiO}_{2}$ corresponds to $\sim 5 \% \mathrm{P}_{2} \mathrm{O}_{5} / \mathrm{TiO}_{2}$ (25). There is no apparent change of the $R$ aman features of the surface vanadium oxide species during butane oxidation at various temperatures. Thus, the surface vanadium oxide species on $\mathrm{P}_{2} \mathrm{O}_{5} / \mathrm{TiO}_{2}$ do not appear to be reduced during butane oxidation.

$6 \% \mathrm{WO}_{3} / 1 \% \mathrm{~V}_{2} \mathrm{O}_{5} / \mathrm{TiO}_{2}$. The in situ $\mathrm{R}$ aman spectra of the $6 \% \mathrm{WO}_{3} / 1 \% \mathrm{~V}_{2} \mathrm{O}_{5} / \mathrm{TiO}_{2}$ catalyst during butane oxidation are presented in Fig. 9. The dehydrated surface vanadium oxide species ( $R$ aman band at $\sim 1028 \mathrm{~cm}^{-1}$ due to terminal $\mathrm{V}=\mathrm{O}$ bond) and surface tungsten oxide species ( $R$ aman band at $\sim 1012 \mathrm{~cm}^{-1}$ due to $\mathrm{W}=0$ bond) coexist on the titinia surface. Monolayer coverage of the surface tungsten oxide species corresponds to $\sim 8 \% \mathrm{WO}_{3} / \mathrm{TiO}_{2}(20)$. The R aman intensity of the dehydrated surface vanadium oxide species decreases somewhat in the butane oxidation environment, but the R aman intensity of the surface tungsten oxide species remains unaffected. The presence of the $\mathrm{R}$ aman feature at $\sim 920 \mathrm{~cm}^{-1}$ indicates that the addition of tungsten oxide to the $1 \% \mathrm{~V}_{2} \mathrm{O}_{5} / \mathrm{TiO}_{2}$ sample affects the surface vanadia coverage and somewhat increases the concentration of the surface polyvanadate functionalities

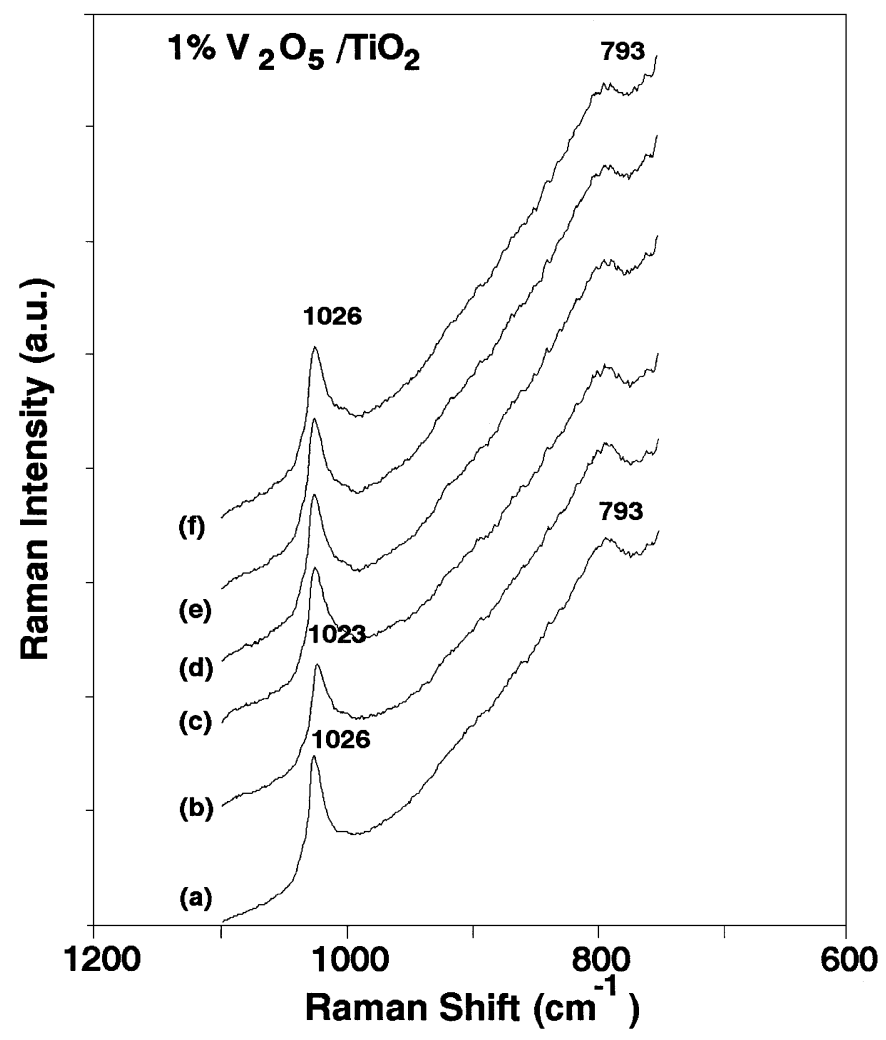

FIG. 6. In situ R aman spectra of the $1 \% \mathrm{~V}_{2} \mathrm{O}_{5} / \mathrm{TiO}_{2}$ catalyst during n-butane oxidation. (a) $\mathrm{O}_{2}, 100 \mathrm{~cm}^{3} / \mathrm{min}, 503 \mathrm{~K}$; (b) $\mathrm{C}_{4} \mathrm{H}_{10} / \mathrm{O}_{2} / \mathrm{H} \mathrm{e}, 100 \mathrm{~cm}^{3} /$ $\min , 503 \mathrm{~K}$; (c) $\mathrm{C}_{4} \mathrm{H}_{10} / \mathrm{O}_{2} / \mathrm{He}, 100 \mathrm{~cm}^{3} / \mathrm{min}, 573 \mathrm{~K}$; (d) $\mathrm{C}_{4} \mathrm{H}_{10} / \mathrm{O}_{2} / \mathrm{He}, 100$ $\mathrm{cm}^{3} / \min , 623 \mathrm{~K}$; (e) $\mathrm{C}_{4} \mathrm{H}_{10} / \mathrm{O}_{2} / \mathrm{He}, 50 \mathrm{~cm}^{3} / \mathrm{min}, 623 \mathrm{~K}$; (f) $\mathrm{O}_{2}, 623 \mathrm{~K}$. 


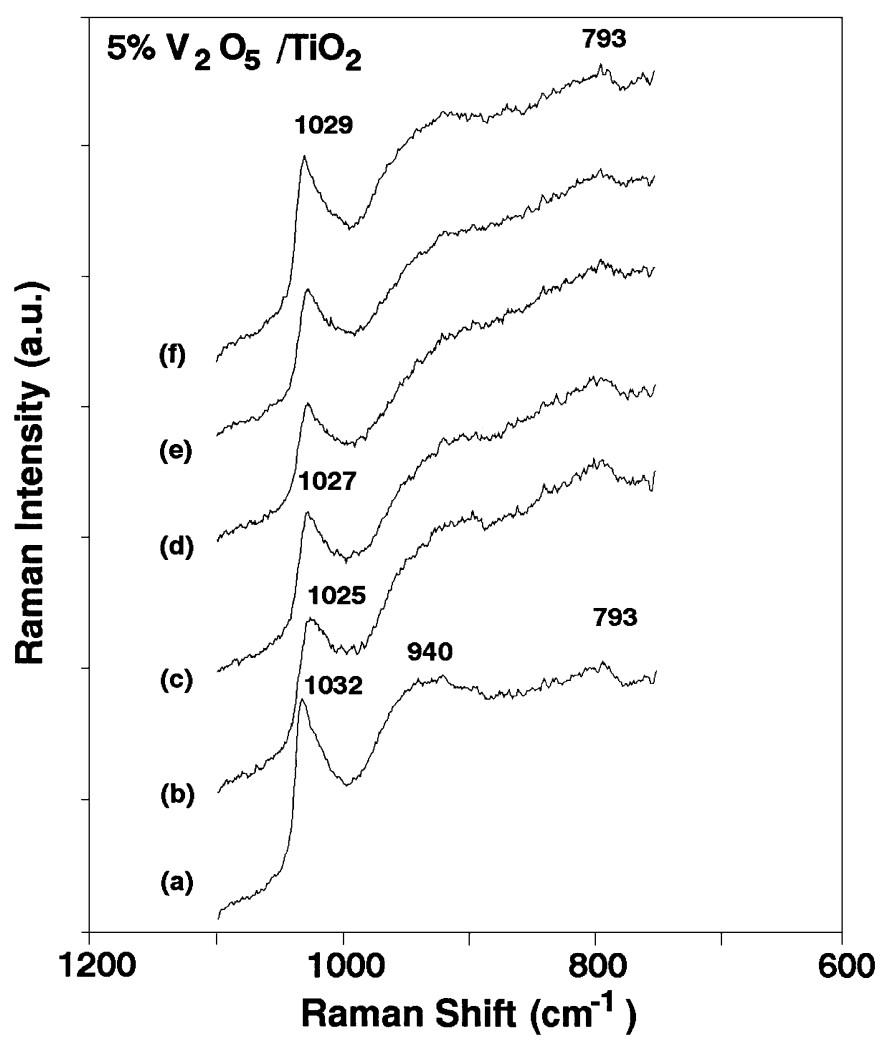

FIG. 7. In situ Raman spectra of the $5 \% \quad \mathrm{~V}_{2} \mathrm{O}_{5} / \mathrm{TiO}_{2}$ catalyst during n-butane oxidation. (a) $\mathrm{O}_{2}, 100 \mathrm{~cm}^{3} / \mathrm{min}, 503 \mathrm{~K}$; (b) $\mathrm{C}_{4} \mathrm{H}_{10} / \mathrm{O}_{2} / \mathrm{He}$, $100 \mathrm{~cm}^{3} / \mathrm{min}, 503 \mathrm{~K}$; (c) $\mathrm{C}_{4} \mathrm{H}_{10} / \mathrm{O}_{2} / \mathrm{H} \mathrm{e}, 100 \mathrm{~cm}^{3} / \mathrm{min}, 573 \mathrm{~K}$; (d) $\mathrm{C}_{4} \mathrm{H}_{10} /$ $\mathrm{O}_{2} / \mathrm{H} \mathrm{e}, 100 \mathrm{~cm}^{3} / \mathrm{min}, 623 \mathrm{~K}$; (e) $\mathrm{C}_{4} \mathrm{H}_{10} / \mathrm{O}_{2} / \mathrm{He}, 50 \mathrm{~cm}^{3} / \mathrm{min}, 623 \mathrm{~K}$; (f) $\mathrm{O}_{2}$, $623 \mathrm{~K}$.

(compare Figs. 6 and 9). N either crystalline $\mathrm{V}_{2} \mathrm{O}_{5}$ nor $\mathrm{WO}_{3}$ $R$ aman features $\left(\sim 805, \sim 710\right.$, and $\left.\sim 320 \mathrm{~cm}^{-1}\right)$ were present in this series of experiments.

\section{O xygen-18 $L$ abeled Studies}

In situ R aman studies employing labeled oxygen-18 were also performed to obtain additional insight into the nature of the metal oxide functionalities participating in the butane oxidation reaction. In these oxygen-18-labeled studies, the $V={ }^{16} \mathrm{O}$ bonds were replaced with $\mathrm{V}={ }^{18} \mathrm{O}$ bonds by reduction in a butane/H e stream and reoxidation with an ${ }^{18} \mathrm{O}_{2} / \mathrm{H}$ e mixture at $723 \mathrm{~K}$. This oxygen exchange resulted in shifting the Raman band associated with the terminal $V=0$ group from 1025 to $983 \mathrm{~cm}^{-1}$ as shown in Fig. 10 for the $4 \% \mathrm{~V}_{2} \mathrm{O}_{5} / \mathrm{ZrO}_{2}$. The bridging oxygen in the $\mathrm{V}-\mathrm{O}-\mathrm{V}$ functionality was also exchanged by this treatment. However, this exchange is not readily detected in Fig. 10 because of the broad V-O-V R aman features and short data collection times employed for the oxygen exchange during butane oxidation. The $\mathrm{V}_{2} \mathrm{O}_{5} / \mathrm{ZrO}_{2}$ catalyst system was chosen for these oxygen exchange experiments because preliminary studies showed that this exchange can be readily achieved with this catalytic system. The oxygen exchange was not to- tally complete since some $\mathrm{V}={ }^{16} \mathrm{O}$ still remained after the oxygen-18 exchange process due to a small air leak in the in situ cell. The $600 \mathrm{~cm}^{-1} \mathrm{R}$ aman band in Fig. 10 is due to the $\mathrm{ZrO}_{2}$ support (see $\mathrm{R}$ ef. (24)). The butane oxidation was carried out over this oxygen-exchanged catalyst at $573 \mathrm{~K}$ in the in situ R aman cell in order to monitor the lifetime of the $\mathrm{V}={ }^{18} \mathrm{O}$ bond during this reaction. A s shown in Fig. 10, approximately half of the $\mathrm{V}={ }^{18} \mathrm{O}$ groups was still present after $17 \mathrm{~min}$ of reaction and after $25 \mathrm{~min}$ essentially no $V={ }^{18} \mathrm{O}$ could be detected. The conversion of butane under these conditions was monitored with an on-line mass spectrometer and found to be ca. 3\% (the selectivity could not be determined because the lines to the mass spectrometer were not sufficiently heated).

\section{K inetic Studies}

The results of $n$-butane oxidation over a number of supported vanadia catalysts are summarized in Tables 1-3. A s shown in Tables 1-3, two important observations can be made: (i) maleic anhydride was the dominant partial oxidation product of n-butane oxidation over these supported vanadia catalysts, and (ii) selective oxidation of $n$-butane to maleic anhydride on supported vanadia catalysts took place at a much lower temperature than in the case of

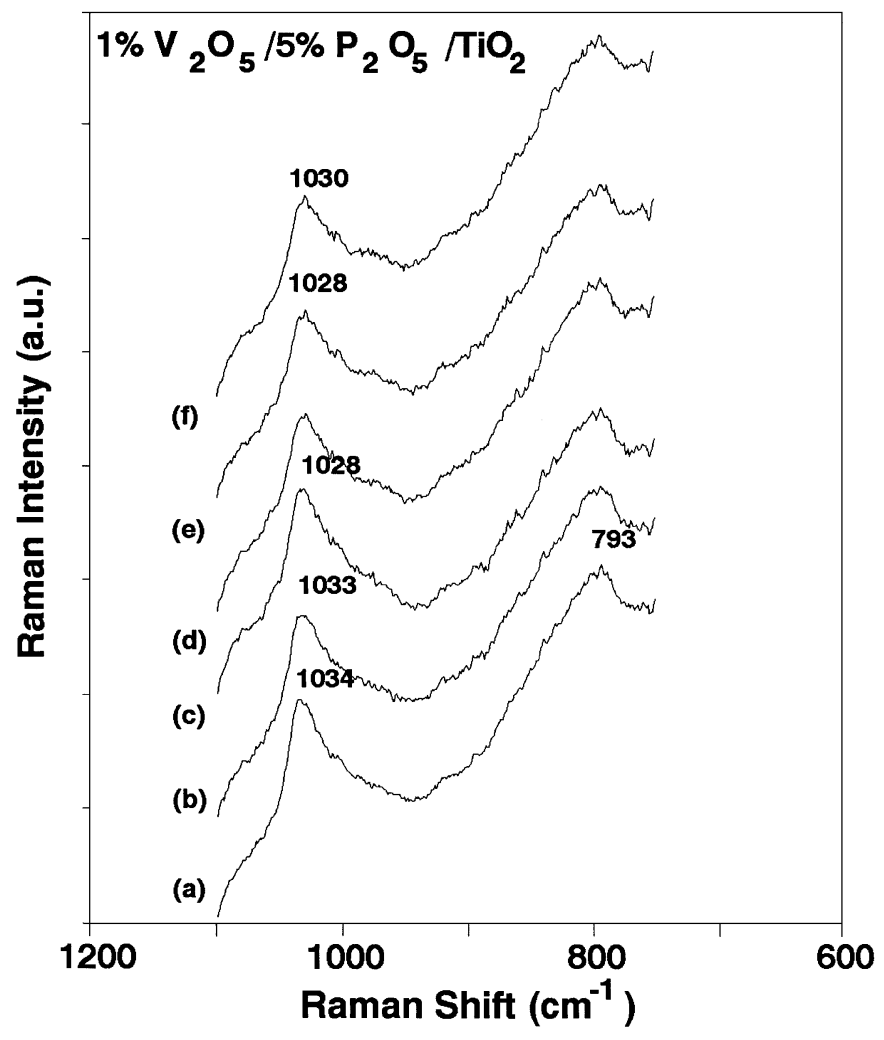

FIG. 8. In situ $\mathrm{R}$ aman spectra of the $1 \% \mathrm{~V}_{2} \mathrm{O}_{5} / 5 \% \quad \mathrm{P}_{2} \mathrm{O}_{5} / \mathrm{TiO}_{2}$ catalyst during n-butane oxidation. (a) $\mathrm{O}_{2}, 100 \mathrm{~cm}^{3} / \mathrm{min}, 503 \mathrm{~K}$; (b) $\mathrm{C}_{4} \mathrm{H}_{10} / \mathrm{O}_{2} / \mathrm{He}$, $100 \mathrm{~cm}^{3} / \mathrm{min}, 503 \mathrm{~K}$; (c) $\mathrm{C}_{4} \mathrm{H}_{10} / \mathrm{O}_{2} / \mathrm{He}, 100 \mathrm{~cm}^{3} / \mathrm{min}, 573 \mathrm{~K}$; (d) $\mathrm{C}_{4} \mathrm{H}_{10} / \mathrm{O}_{2} /$ $\mathrm{He}, 100 \mathrm{~cm}^{3} / \mathrm{min}, 623 \mathrm{~K}$; (e) $\mathrm{C}_{4} \mathrm{H}_{10} / \mathrm{O}_{2} / \mathrm{He}, 50 \mathrm{~cm}^{3} / \mathrm{min}, 623 \mathrm{~K}$; (f) $\mathrm{O}_{2}, 623 \mathrm{~K}$. 


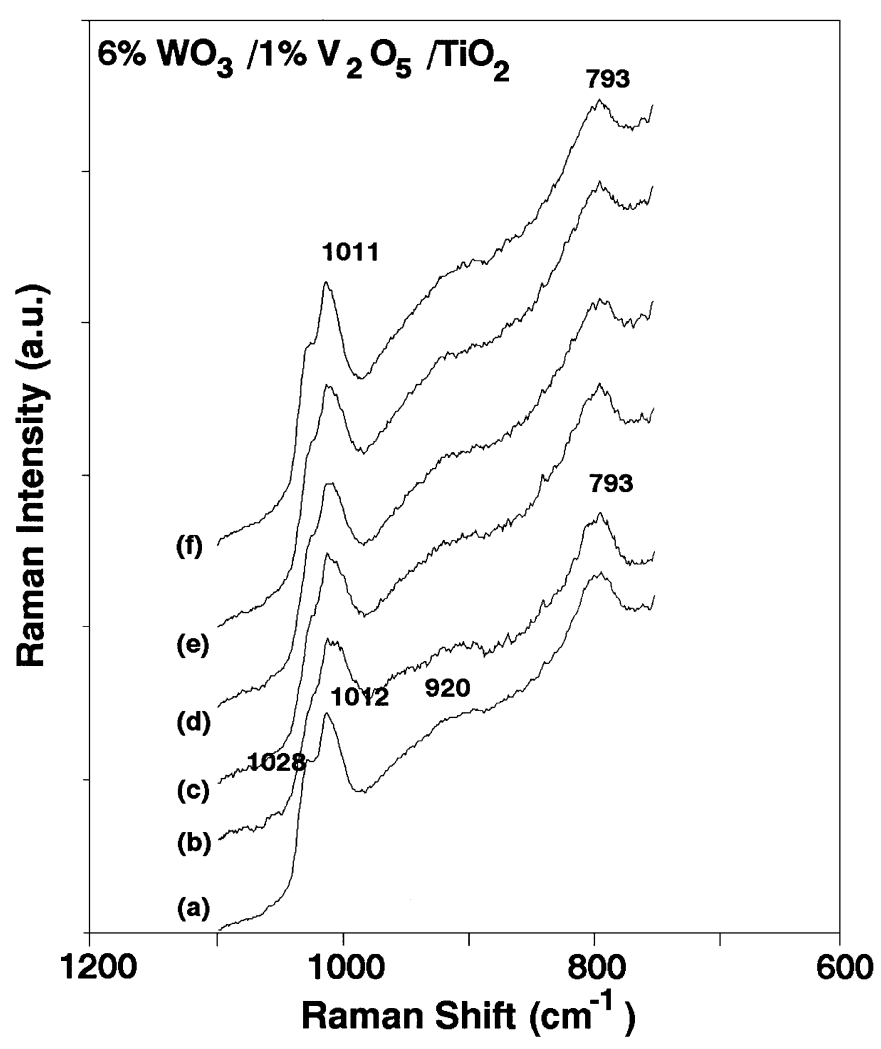

FIG. 9. In situ Raman spectra of the $6 \% \quad \mathrm{WO}_{3} / 1 \% \quad \mathrm{~V}_{2} \mathrm{O}_{5} / \mathrm{TiO}_{2}$ catalyst during n-butane oxidation. (a) $\mathrm{O}_{2}, 100 \mathrm{~cm}^{3} / \mathrm{min}, 503 \mathrm{~K}$; (b) $\mathrm{C}_{4} \mathrm{H}_{10} / \mathrm{O}_{2} / \mathrm{He}, 100 \mathrm{~cm}^{3} / \mathrm{min}, 503 \mathrm{~K}$; (c) $\mathrm{C}_{4} \mathrm{H}_{10} / \mathrm{O}_{2} / \mathrm{H} \mathrm{e}, 100 \mathrm{~cm}^{3} / \mathrm{min}, 573 \mathrm{~K}$; (d) $\mathrm{C}_{4} \mathrm{H}_{10} / \mathrm{O}_{2} / \mathrm{H} \mathrm{e}, 100 \mathrm{~cm}^{3} / \mathrm{min}, 623 \mathrm{~K}$; (e) $\mathrm{C}_{4} \mathrm{H}_{10} / \mathrm{O}_{2} / \mathrm{H} \mathrm{e}, 50 \mathrm{~cm}^{3} / \mathrm{min}, 623 \mathrm{~K}$; (f) $\mathrm{O}_{2}, 623 \mathrm{~K}$.

conventional V PO catalysts ( $494 \mathrm{~K}$ vs $650 \mathrm{~K}$ ). For the catalysts containing approximately a monolayer coverage of surface vanadia (with the exception of vanadia/silica that possessed only ca. a quarter monolayer coverage), the butane oxidation turnover frequency (TOF), the number of n-butane molecules converted per vanadium per second, was a strong function of the specific oxide support and varied by a factor of $\sim 50$ ( see Table 1 ). The vanadia/silica sys-

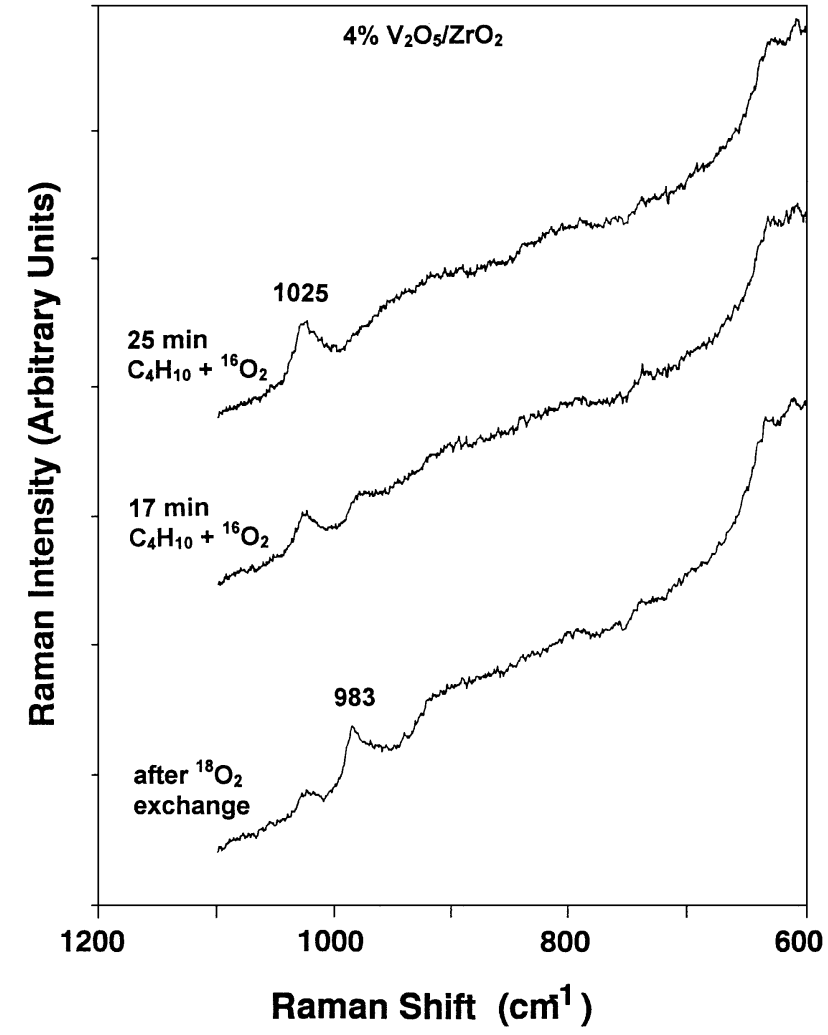

FIG. 10. In situ R aman spectra of ${ }^{18} \mathrm{O}$-labeled $4 \% \mathrm{~V}_{2} \mathrm{O}_{5} / \mathrm{Z} \mathrm{rO}_{2}$ catalyst during $\mathrm{n}$-butane oxidation at $494 \mathrm{~K}$ in $1.2 \mathrm{vol} . \% \mathrm{n}$-butane in air.

tem was the least active catalyst and the vanadia/titania system was the most active catalyst for butane oxidation. The general activity pattern was $\mathrm{Ti}>\mathrm{Ce}>\mathrm{Zr} \sim \mathrm{Nb}>\mathrm{Al}>\mathrm{Si}$. The corresponding maleic anhydride TOF for these catalysts was $\mathrm{Ti}>\mathrm{Nb}>\mathrm{Ce}>\mathrm{Zr} \sim \mathrm{Al} \gg \mathrm{Si}$. Thus, the vanadia/titania catalyst system was the most efficient catalyst for the oxidation of butane to maleic anhydride over the supported vanadia catalysts.

The vanadia/titania catalysts were further investigated because of the relatively favorable properties of this catalyst

TABLE 1

The E ffect of the Metal Oxide Support on $n$-B utane Oxidation on Supported Vanadia Catalysts at $494 \mathrm{~K}$ in $1.2 \mathrm{vol} . \% n$-Butane in Air

\begin{tabular}{lcccccc}
\hline \multicolumn{1}{c}{ Catalyst } & $\begin{array}{c}\text { Weight } \\
(\mathrm{g})\end{array}$ & $\begin{array}{c}\text { Flow } \\
\left(\mathrm{cm}^{3} / \mathrm{min}\right)\end{array}$ & $\begin{array}{c}\text { Butane conversion } \\
(\mathrm{mol} \% \%)\end{array}$ & $\begin{array}{c}\mathrm{MA}^{\text {a }} \text { selectivity } \\
(\mathrm{mol} \%)\end{array}$ & $\begin{array}{r}\text { Butane TOF } \\
\left(10^{-5} \mathrm{~s}^{-1}\right)\end{array}$ & $\begin{array}{c}\text { MA TOF } \\
\left(10^{-5} \mathrm{~s}^{-1}\right)\end{array}$ \\
\hline $7 \% \mathrm{~V}_{2} \mathrm{O}_{5} / \mathrm{SiO}_{2}{ }^{\mathrm{b}}$ & 0.577 & 7.4 & 2.8 & 91.8 & 0.4 & 0.3 \\
$17.5 \% \mathrm{~V}_{2} \mathrm{O}_{5} / \mathrm{Al}_{2} \mathrm{O}_{3}$ & 0.625 & 17.8 & 7.2 & 44.5 & 0.9 & 0.4 \\
$6 \% \mathrm{~V}_{2} \mathrm{O}_{5} / \mathrm{N} \mathrm{b}_{2} \mathrm{O}_{5}$ & 0.885 & 13.9 & 17.3 & 36.7 & 3.6 & 1.3 \\
$4 \% \mathrm{~V}_{2} \mathrm{O}_{5} / \mathrm{ZrO}_{2}$ & 0.794 & 11.3 & 16.0 & 9.3 & 4.5 & 0.4 \\
$3 \% \mathrm{~V}_{2} \mathrm{O}_{5} / \mathrm{CeO}_{2}$ & 0.622 & 14.2 & 10.6 & 30.6 & 6.3 & 0.8 \\
$5 \% \mathrm{~V}_{2} \mathrm{O}_{5} / \mathrm{TiO}_{2}$ & 0.566 & 25.5 & 27.8 & & 19.6 & 6.0 \\
\hline
\end{tabular}

\footnotetext{
${ }^{a} \mathrm{MA}$, maleic anhydride.

${ }^{b}$ Considerable error is involved in determining the MA selectivity for this sample due to the extremely low conversion.
} 
TABLE 2

Performance of Titania Support in $n$-B utane Oxidation at $494 \mathrm{~K}$ in 1.2 vol.\% $n$-B utane in Air

\begin{tabular}{lcccccc}
\hline \multicolumn{1}{c}{ Catalyst } & $\begin{array}{c}\text { Weight } \\
(\mathrm{g})\end{array}$ & $\begin{array}{c}\text { Flow } \\
\left(\mathrm{cm}^{3} / \mathrm{min}\right)\end{array}$ & $\begin{array}{c}\text { Butane conversion } \\
(\mathrm{mol} . \%)\end{array}$ & $\begin{array}{c}\text { M A selectivity } \\
(\mathrm{mol} . \%)\end{array}$ & $\begin{array}{c}\text { Butane TOF } \\
\left(10^{-5} \mathrm{~s}^{-1}\right)\end{array}$ & $\begin{array}{c}\text { M A TOF } \\
\left(10^{-5} \mathrm{~s}^{-1}\right)\end{array}$ \\
\hline $1 \% \mathrm{~V}_{2} \mathrm{O}_{5} / \mathrm{TiO}_{2}$ & 0.890 & 8.7 & 16.0 & 22.8 & 12.4 & 2.8 \\
$2 \% \mathrm{~V}_{2} \mathrm{O}_{5} / \mathrm{TiO}_{2}$ & 0.612 & 17.6 & 24.2 & 9.9 & 27.7 & 2.7 \\
$3 \% \mathrm{~V}_{2} \mathrm{O}_{5} / \mathrm{TiO}_{2}$ & 0.603 & 19.9 & 27.0 & 17.0 & 23.4 & 4.0 \\
$4 \% \mathrm{~V}_{2} \mathrm{O}_{5} / \mathrm{TiO}_{2}$ & 0.700 & 30.7 & 30.7 & 29.9 & 25.5 & 6.6 \\
$5 \% \mathrm{~V}_{2} \mathrm{O}_{5} / \mathrm{TiO}_{2}$ & 0.566 & 25.5 & 27.8 & 30.5 & 19.6 & 6.0 \\
$7 \% \mathrm{~V}_{2} \mathrm{O}_{5} / \mathrm{TiO}_{2}$ & 0.572 & 21.9 & 18.5 & 24.7 & 8.0 & 2.0 \\
\hline
\end{tabular}

system for the partial oxidation of butane to maleic anhydride. The $\mathrm{TiO}_{2}$ support was essentially inactive for butane oxidation. The influence of surface vanadia coverage on titania upon the activity and selectivity of butane oxidation to maleic anhydride are presented in Table 2 and Fig. 11. The butane oxidation TOF is relatively constant below monolayer coverage $\left(\sim 6 \% \mathrm{~V}_{2} \mathrm{O}_{5} / \mathrm{TiO}_{2}\right)$. A lthough the butane oxidation TOF for the $\mathrm{V}_{2} \mathrm{O}_{5} / \mathrm{TiO}_{2}$ catalystsincreases slightly at low vanadia coverage, this increase is almost within the experimental error. H owever, the butane oxidation TOF decreases some $50 \%$ at coverages above monolayer because of the presence of microcrystalline $\mathrm{V}_{2} \mathrm{O}_{5}$ particles in this sample. The maleic anhydride TOF depends somewhat on the surface vanadia coverage and increases by a factor of 2 to 3 up to monolayer coverage. A bove monolayer coverage, the maleic anhydride TO F declines, reflecting the lower activity of microcrystalline $\mathrm{V}_{2} \mathrm{O}_{5}$ particles for the oxidation of butane. Thus, both the butane oxidation and the maleic TOF sare influenced by the surface vanadia coverage on the titania support and the most efficient catalyst corresponds to monolayer coverage.

The influence of acidic promoters upon butane oxidation over the $1 \% \mathrm{~V}_{2} \mathrm{O}_{5} / \mathrm{TiO}_{2}$ catalyst is summarized in Table 3. A II the acidic additives had a positive effect on both butane and maleic TOFs. The addition of surface tungsten oxide species in the case of the $6 \% \mathrm{WO}_{3} / 1 \% \mathrm{~V}_{2} \mathrm{O}_{5} / \mathrm{TiO}_{2}$ catalyst had a modest effect on both the butane oxidation and the maleic TOFs. However, the presence of microcrystalline $\mathrm{WO}_{3}$ particles in the $9 \% \mathrm{WO}_{3} / 1 \% \mathrm{~V}_{2} \mathrm{O}_{5} / \mathrm{TiO}_{2}$ catalyst cancelled the positive influence of the surface tungsten oxide species on the maleic TOF. The addition of surface niobia species in the $6 \% \mathrm{Nb}_{2} \mathrm{O}_{5} / 1 \% \mathrm{~V}_{2} \mathrm{O}_{5} / \mathrm{TiO}_{2}$ catalyst had a more positive effect on both the butane oxidation and the maleic anhydride TOFs. The surface phosphorus oxide additive, however, most significantly enhanced the maleic anhydride TOF because of the high maleic selectivity. Thus, the butane oxidation and maleic TOFs are positively influenced by the presence of acidic surface metal oxide additives. $\mathrm{M} \mathrm{i-}$ crocrystalline metal oxide particles, $\mathrm{WO}_{3}$, appear to have a detrimental effect on this reaction.

\section{DISCUSSION}

The molecular structure of the surface vanadia species supported on metal oxides has been extensively characterized with molecular spectroscopies ( $R$ aman, IR, solid state vanadium-51 NMR and EXAFS/XANES) in recent years (13). U nder dehydrated conditions, the surface vanadia species possess terminal $V=0$ groups and polymeric functionalities associated with isolated and polymerized species on the oxide supports $(20,22,26)$. The silica support represents one exception where only isolated surface vanadia species exist. The surface vanadia species contain only one terminal $V=0$ bond, mono-oxo (27), and three bridging $\mathrm{V}-\mathrm{O}-\mathrm{M}^{\prime}$ bonds, where $\mathrm{M}^{\prime}$ is either another $\mathrm{V}$ atom or the oxide support cation $(22,28)$. The in situ $R$ aman spectra collected in flowing oxygen at 503 and $623 \mathrm{~K}$ (Figs. 1-9) correspond to the dehydrated surface vanadia species on the different oxide supports. The terminal $V=0$ vibrations for such dehydrated species occur at $1026-1038 \mathrm{~cm}^{-1}$. These

\section{TABLE 3}

The E ffect of A cidic Promoters on $n$-Butane Oxidation on the $1 \% \mathrm{~V}_{2} \mathrm{O}_{5} / \mathrm{TiO} \mathrm{O}_{2}$ C atalyst at $494 \mathrm{~K}$ in 1.2 vol.\% $n$-Butane in Air

\begin{tabular}{lcccccr}
\hline Catalyst & $\begin{array}{c}\text { Weight } \\
(\mathrm{g})\end{array}$ & $\begin{array}{c}\text { Flow } \\
\left(\mathrm{cm}^{3} / \mathrm{min}\right)\end{array}$ & $\begin{array}{c}\text { Butane conversion } \\
(\mathrm{mol} . \%)\end{array}$ & $\begin{array}{c}\text { M A selectivity } \\
(\mathrm{mol} . \%)\end{array}$ & $\begin{array}{r}\text { Butane TOF } \\
\left(10^{-5} \mathrm{~s}^{-1}\right)\end{array}$ & $\begin{array}{r}\text { M A TOF } \\
\left(10^{-5} \mathrm{~s}^{-1}\right)\end{array}$ \\
\hline $1 \% \mathrm{~V}_{2} \mathrm{O}_{5} / 5 \% \mathrm{P}_{2} \mathrm{O}_{5} / \mathrm{TiO}_{2}$ & 0.172 & 5.0 & 12.1 & 56.2 & 27.0 & 15.2 \\
$6 \% \mathrm{WO}_{3} / 1 \% \mathrm{~V}_{2} \mathrm{O}_{5} / \mathrm{TiO}_{2}$ & 0.708 & 8.9 & 23.6 & 26.2 & 34.1 & 8.9 \\
$9 \% \mathrm{WO}_{3} / 1 \% \mathrm{~V}_{2} \mathrm{O}_{5} / \mathrm{TiO}_{2}$ & 0.465 & 11.1 & 14.8 & 6.8 & 40.5 & 2.8 \\
$6 \% \mathrm{Nb}_{2} \mathrm{O}_{5} / 1 \% \mathrm{~V}_{2} \mathrm{O}_{5} / \mathrm{TiO}_{2}$ & 0.181 & 7.5 & 10.7 & 35.1 & 50.8 & 17.8 \\
\hline
\end{tabular}




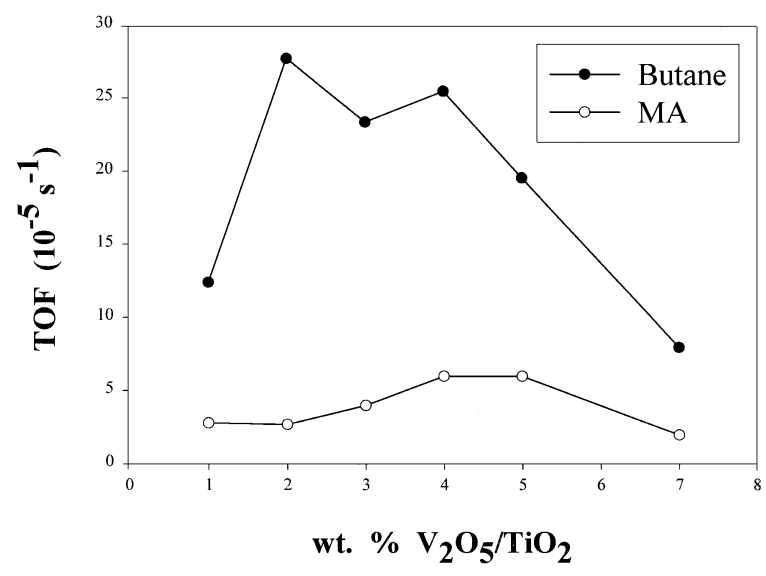

FIG. 11. Performance of titania support in n-butane oxidation on supported vanadia catalyst at $494 \mathrm{~K}$ in 1.2 vol.\% n-butane in air.

dehydrated surface vanadia species can become hydrated in the presence of moisture $(24,29)$. A t temperatures below $\sim 473 \mathrm{~K}$, the amount of adsorbed moisture can be significant, equivalent to several monolayers of water. This adsorbed water can cause the hydrolysis of the bridging $\mathrm{V}$-O-support bonds with the resulting formation of hydrated vanadium oxide clusters. A t temperatures of 473$573 \mathrm{~K}$, the amount of adsorbed moisture present on the surface corresponds to submonolayer quantities and the adsorbed water molecules coordinate to the oxygen functionalities via hydrogen bonding. The in situ $\mathrm{R}$ aman spectra during butane oxidation at $503 \mathrm{~K}$ reflect the presence of submonolayer quantities of adsorbed moisture in the slight shift, $\sim 0-7 \mathrm{~cm}^{-1}$, of the terminal $V=0 \mathrm{R}$ aman bands to lower wavenumbers. A temperatures in excess of $573 \mathrm{~K}$, the amount of the adsorbed moisture present on the supported vanadia catalysts is further reduced and the influence of adsorbed moisture on the in situ Raman spectra is almost undetectable. The in situ $\mathrm{R}$ aman spectra during butane oxidation at 503-673 $\mathrm{K}$ reveal that the dehydrated surface vanadia species are stable in the reaction environment and do not agglo merate to form microcrystalline $\mathrm{V}_{2} \mathrm{O}_{5}$ particles even in the presence of small amounts of adsorbed moisture.

The in situ R aman spectra during butane oxidation at $573 \mathrm{~K}$ and higher temperatures also reveal that the surface vanadia species can become partially reduced by the reaction environment (reflected by a decrease in the Raman intensity in Figs. 1-9). It also appears that the polymeric functionalities, manifested in broad $\mathrm{R}$ aman bands below $1000 \mathrm{~cm}^{-1}$, are somewhat more reducible than the terminal $V=0$ groups ( $R$ aman bands at $1020-1040 \mathrm{~cm}^{-1}$ ). For example, the reduction of the polymeric functionalities is more extensive than the terminal $\mathrm{V}=0$ groups during butane oxidation over the vanadia/alumina catalyst. H owever, we did not observe a relationship between the extent of reduction of the surface vanadia species and the butane oxidation TOF. The extent of reduction of the surface vanadia species during butane oxidation over the supported vanadia catalysts containing approximately monolayer coverage followed the pattern $\mathrm{Al}>\mathrm{Ti}>\mathrm{Zr} \sim \mathrm{Nb} \sim \mathrm{Ce} \gg \mathrm{Si}$. Furthermore, both the $1 \%$ and the $5 \% \mathrm{~V}_{2} \mathrm{O}_{5} / \mathrm{TiO}_{2}$ catalysts were very active for butane oxidation, but the $1 \%$ catalyst did not exhibit any reduction and the $5 \%$ catalyst exhibited some reduction during butane oxidation. The maleic anhydride selectivity did not appear to directly correlate with the extent of reduction, since the selectivity pattern is $\mathrm{Al}>\mathrm{Nb}>\mathrm{Ti}>\mathrm{Si}>\mathrm{Zr} \sim \mathrm{Ce}$. Furthermore, the most active and selective catalyst, $1 \% \mathrm{~V}_{2} \mathrm{O}_{5} / 5 \% \mathrm{P}_{2} \mathrm{O}_{5} / \mathrm{TiO}_{2}$, was not reduced during butane oxidation (see Fig. 8). Thus, the extent of reduction of the surface vanadia species during butane oxidation does not appear to relate to the butane oxidation TOF and the maleic anhydride selectivity.

The $\mathrm{R}$ aman band positions during butane oxidation suggest that the terminal vanadyl oxygen is not involved in the critical kinetic steps of this reaction (most likely the activation of butane). A t near monolayer coverages, the R aman band positions of the terminal $\mathrm{V}=0$ stretch occur between 1027 and $1032 \mathrm{~cm}^{-1}$ for the dehydrated catalysts and 1025 and $1028 \mathrm{~cm}^{-1}$ during butane oxidation at $503 \mathrm{~K}$, with the exception of vanadia/silica catalyst which possesses approximately a quarter monolayer of surface vanadia species and has a $R$ aman band at $1038 \mathrm{~cm}^{-1}$. The $R$ aman band position of the terminal $V=0$ stretch is directly related to the $V=0$ bond strength (30). H owever, the R aman band positions of the terminal $\mathrm{V}=0$ group for the supported vanadia catalysts are almost identical, while the butane oxidation TO F simultaneously varies by more than an order of magnitude. Thus, the absence of a relationship between the terminal $\mathrm{V}=\mathrm{O}$ bond strength and the butane oxidation TOF strongly suggests that this functionality is not involved in the critical kinetic steps (most likely the activated adsorption of butane) during butane oxidation.

In situ Raman experiments employing oxygen-18 exchange were also conducted in an attempt to obtain additional insights into the role of the terminal $V=0$ bond during butane oxidation. U nfortunately, the very short data collection times employed during this exchange experiment could not provide any meaningful $R$ aman information associated with the bridging $\mathrm{V}-\mathrm{O}-\mathrm{V}$ functionalities, which also underwent oxygen exchange. The characteristic time required to exchange the ${ }^{18} \mathrm{O}$-labeled terminal vanadyl oxygen during butane oxidation was $t_{e x} \sim 35$ min (when corrected for the incomplete incorporation of oxygen-18 at the beginning of the experiment). This long period of time can not be due to bypassing in the in situ $R$ aman cell since complete exchange occurs in a $\mathrm{H}_{2}{ }^{16} \mathrm{O} /{ }^{16} \mathrm{O}_{2}$ stream in less than 7 min (24) (probably even much faster, but good quality R aman signals cannot be obtained with the current $O \mathrm{M} \mathrm{A}$ detectors for very short collection times). The combined effects of bypassing and strong mass transfer limitations 
in the pressed catalyst wafer do not allow for an accurate determination of the TOF for butane oxidation or the $t_{r x}$, the characteristic reaction time in the in situ $\mathrm{R}$ aman cell. $\mathrm{H}$ owever, the $\mathrm{R}$ aman signal does measure the exterior of the catalyst pellet, i.e., the reaction zone, where the catalyst is directly exposed to the butane/oxygen stream and mass transfer limitations are minimal. The characteristic reaction time, $t_{r x}$, was estimated to be $\sim 100 \mathrm{~s}$ at $573 \mathrm{~K}$ by extrapolating the measured TOF at $494 \mathrm{~K}$ and using the experimental activation energy for butane oxidation over supported vanadia catalysts (31). Thus, to a first approximation, the ratio of the two characteristic reaction times is $t_{e x} / t_{r x} \sim 20$, which suggests that the terminal $V=0$ bond is relatively stable during butane oxidation (surviving 20 reaction cycles). However, more accurate measurements need to be performed with in situ R aman cells containing packed beds of catalysts. Such in situ cell implementation will prevent bypassing and minimize mass transfer limitations associated with the pressed catalyst wafers employed in the present study. M oreover, faster R aman detectors will also aid in completely resolving the issue of the stability of the $\mathrm{V}=0$ bond during butane oxidation.

The lack of correlation of the terminal $V=0$ bond stability with the butane oxidation TOFs shifts attention to the bridging $\mathrm{V}-\mathrm{O}-\mathrm{M}^{\prime}$. The bridging $\mathrm{V}-\mathrm{O}-\mathrm{V}$ bonds in the polymeric surface vanadia species do not contribute to a significant change in the butane oxidation TOF. For example, the concentration of polymerized surface functionalities increases with vanadium oxide coverage on titania (compare $1 \%$ and $5 \% \mathrm{~V}_{2} \mathrm{O}_{5} / \mathrm{TiO}_{2} \mathrm{R}$ aman spectra in Figs. 6 and 7), but the butane oxidation TOF does not significantly change within experimental error. However, changing the specific oxide support does have a significant effect on the butane oxidation TOF as shown in Table 1. This observation suggests that the bridging $\mathrm{V}-\mathrm{O}$-support bonds may be involved in the critical kinetic steps of butane oxidation. In order to verify the hypothesis that the $\mathrm{V}$-O-support bonds are involved in the $\mathrm{C}-\mathrm{H}$ bond activation, we resorted to the concepts of the density functional theory (32): the absolute hardness, $h$, the absolute electronegativity, c (33), and the principle of hard and soft acids and bases, or HSA B (34). H owever, the catalytic activity of supported vanadia catalysts in the heterolytic $\mathrm{C}-\mathrm{H}$ bond cleavage did not correlate with the hardness of metal in the metal oxide support and, therefore, with the higher electron density on the bridging oxygen. Furthermore, the straightforward correlation between the electronegativity of the oxide support metal and the activity of the supported vanadia catalysts in n-butane oxidation is not observed when the Pauling (35) and Sanderson (36) scales of electronegativity are employed. R ecently, $\mathrm{H}$ aber et al. have studied n-butane oxidation on a number of promoted bulk VPO catalysts (19). They found that the activity of the promoted V PO catalysts in n-butane oxidation correlated with the surface basicity measured by the $\mathrm{CO}_{2}$ adsorption and the effective negative charge on surface oxygen atoms from the X PS experiments. Therefore, we believe that additional characterization of vanadia monolayers on the above supports, such as measurements of basicity, the binding energy of oxygen 1selectrons, is necessary to both understand the fundamentals of hydrocarbon activation by supported monolayer catalysts and establish further mechanistic parallels between supported vanadia and bulk VPO catalysts for n-butane oxidation.

The maleic anhydride selectivity trends reveal that the electronegativity $(33,35,36)$ properties of the bridging $\mathrm{V}$-O-support bond are not related to selectivity since the selectivity trend is $\mathrm{Al}>\mathrm{Nb}>\mathrm{Ti}>\mathrm{Si}>\mathrm{Zr}>\mathrm{Ce}$. This selectivity trend parallels the strength of the L ewis acidity of the oxide supports since alumina has the strongest L ewis acid sites followed by niobia; the other supports have very weak (titania and zirconia) or no Lewis acid sites (silica) (37). This observation is in agreement with the results of $\mathrm{H}$ aber et al. (19), who found that selectivity to maleic anhydride on promoted V PO catalysts correlated with the surface acidity. The low selectivity of the vanadia/ceria catalyst may be related to the ability of ceria to directly supply oxygen to reactants or products which may result in nonselective reactions (38). The maleic anhydride TOF and selectivity, however, do appear to increase with increasing surface vanadia coverage on titania or decreasing average distance between surface vanadia species (see Fig. 11 and Table 2). This trend suggests that the efficiency for maleic anhydride formation may be related to the presence of two adjacent surface vanadia sites. This observation is reminiscent of the mechanism of n-butane oxidation on bulk VPO catalysts proposed by Trifirò etal. (6), who found that the rates of hydrocarbon oxidation on the V PO catalysts correlated with the process of simultaneous abstraction of two methylene hydrogen atoms and proposed an active site for butane oxidation based on vanadyl dimers present in the (100) plane of vanadyl pyrophosphate, ( VO ) ${ }_{2} \mathrm{P}_{2} \mathrm{O}_{7}$ (6). The current butane oxidation kinetics on the supported vanadia catalysts also reveal that both isolated and adjacent surface vanadia species are able to oxidize butane to maleic anhydride. For example, maleic anhydride is formed from vanadia/silica catalysts and the $1 \% \mathrm{~V}_{2} \mathrm{O}_{5} / \mathrm{TiO}_{2}$ catalysts where the isolated surface vanadia species is the only species or the dominant species present. The mechanism by which butane is oxidized to maleic anhydride over the surface vanadia species is currently unknown. However, it appears that both isolated and adjacent surface vanadia species can selectively activate butane. $\mathrm{H}$ owever, other factors may also contribute to the increase in maleic anhydride TOF with increasing surface vanadia coverage. The exposed titania sites present at lower surface vanadia coverages may also partially contribute to the lower maleic anhydride TO F since such sites are known to decompose phthalic anhydride during o-xylene oxidation 
over vanadia/titania catalysts (39). The surface concentration of Brønsted acid sites also increases with surface vanadia coverage and may contribute to the efficient formation of maleic anhydride (40). In summary, the maleic anhydride selectivity appears to be optimum near monolayer coverages at a high concentration of adjacent surface vanadia species and in the presence of support cations that possess strong L ewis acid sites.

The enhancement in butane oxidation TOF and maleic selectivity upon the introduction of acidic secondary metal oxide additives further confirms the positive role of acidity in this reaction. The butane oxidation TOF was increased by a factor of 2-3 when acidic surface metal oxide were introduced to the $1 \% \mathrm{~V}_{2} \mathrm{O}_{5} / \mathrm{TiO}_{2}$ catalysts (see Table 3 ). The surface tungsten oxide and niobia species coordinate to the titania support and only interact with the surface vanadia species via lateral interactions in the monolayer (21). The surface niobia species possess very weak B rønsted acid sites (detectable with ammonia adsorption, but not pyridine adsorption). The surface tungsten oxide species possess stronger Brønsted acid sites (detectable by both ammonia and pyridine adsorption), and they are predominantly present as surface Lewis acid sites (41). Thus, the presence of these adjacent acidic metal oxide sites to the surface vanadia species has a beneficial effect on butane oxidation TOF and maleic anhydride selectivity. The surface phosphate species coordinate to the titania support as tridentate hydrogenphosphate species which possess weak B rønsted acid sites (42). U nlike the surface tungsten oxide and niobia, the surface phosphate directly coordinates with the surface vanadia species via reaction of the $\mathrm{P}-\mathrm{OH}$ bonds (21). The formation of this $\mathrm{V}-\mathrm{O}-\mathrm{P}$ bond has a positive effect on the butane oxidation TOF and a significant enhancement of the maleic anhydride selectivity. This observation is consistent with the above observations that bridging $\mathrm{V}-\mathrm{O}-\mathrm{M}$ ' bonds are critical in the oxidation of butane to maleic anhydride and is also in agreement with recent electron microscopy results revealing that the $V-O-P$ bonds are selectively reduced during butane reduction of bulk V-P-O catalysts (43). H owever, the conditions of the electron microscopy experiment were very different from those of conventional V PO catalysis (6). Thus, the incorporation of acidic secondary metal oxide additives to the surface vanadia overlayer has a positive effect on the butane oxidation TOF and maleic anhydride selectivity. Furthermore, the formation of bridging $\mathrm{V}-\mathrm{O}-\mathrm{P}$ bonds significantly enhances the maleic anhydride selectivity.

Comparison of the butane oxidation over supported vanadia catalysts with other oxidation reactions over the same catalysts can provide additional insights into the fundamental aspects of this reaction. The oxidation of methanol to formaldehyde, as well as the formaldehyde selectivity, over supported vanadia catalysts was found to be essentially independent of the surface vanadia coverage
(44). Furthermore, the addition of surface tungsten oxide and niobia species also did not influence the methanol oxidation TOF and the formaldehyde selectivity (21). These observations suggest that this unimolecular oxidation reaction requires only one surface vanadia redox site and is insensitive to its immediate environment. In contrast to methanol oxidation, the selective catalytic oxidation of $\mathrm{NO}$ with ammonia to $\mathrm{N}_{2}$ and water over the supported vanadia catalysts strongly depended on the surface coverage and the presence of the surface tungsten oxide and niobia (an increase of about an order of magnitude in TOF). These observations suggest that the bimolecular D eNOx reaction requires two adjacent surface sites: a surface vanadia redox site and an adjacent surface acid site $(41,45)$. The oxidation of butane over the supported vanadia catalysts does not appear to significantly vary with surface vanadia coverage and the presence of adjacent acidic surface tungsten oxide and niobia species (see Tables 2 and 3), but these parameters appear to have a modest beneficial effect. These observations suggest that the oxidation of butane, most likely the activated adsorption step, essentially requires only one surface vanadia redox site and that adjacent acidic sites have only a second-order effect on butane oxidation. The influence of surface phosphate on the reactivity of the vanadia/titania catalyst system is extremely informative. For methanol oxidation, the addition of the surface phosphate additive decreases the TO $F$ by an order of magnitude due to the replacement of bridging $\mathrm{V}-\mathrm{O}-\mathrm{Ti}$ bonds with $\mathrm{V}-\mathrm{O}-\mathrm{P}$ bonds, and there is a modest decrease in formal dehyde selectivity due to the acidic nature of the surface phosphate group. For butane oxidation, however, the addition of the surface phosphate group and the formation of bridging $\mathrm{V}-\mathrm{O}-\mathrm{P}$ bonds has a positive effect on the TO F and the maleic selectivity. The different responses of these two oxidation reactions reflect their different requirements. The oxidation of methanol to formal dehyde requires only a redox site and the substitution of $\mathrm{V}-\mathrm{O}-\mathrm{P}$ bonds for $\mathrm{V}-\mathrm{O}-\mathrm{Ti}$ bonds decreases the redox activity of the surface vanadia site. The more complex oxidation of butane to maleic anhydride requires both a redox site and some acidic character. Thus, the substitution of less reducible and more acidic $\mathrm{V}-\mathrm{O}-\mathrm{P}$ bonds for $\mathrm{V}-\mathrm{O}-\mathrm{Ti}$ bonds results in an increase in both the butane oxidation TOF and the maleic anhydride selectivity. The different requirements of these two oxidation reactions are also observed in the reaction selectivities when the specific oxide supports are varied. For methanol oxidation, the selectivity towards redox products decreases with increasing $L$ ewis acid strength of the oxide support cation ( $\mathrm{Ti} \sim \mathrm{Zr} \sim \mathrm{Ce}>\mathrm{Nb}>\mathrm{A}$ I). In contrast, for butane oxidation the maleic anhydride selectivity increases with increasing $L$ ewis acid strength of the oxide support cation $(\mathrm{Al}>\mathrm{Nb}>\mathrm{Ti}>\mathrm{Zr} \sim \mathrm{Ce}$ ). For all three oxidation reactions the influence of the specific oxide support on the TOF follows a very similar trend $(\mathrm{Ti} \sim \mathrm{Zr} \sim \mathrm{Ce}>\mathrm{Nb}>\mathrm{Al}>\mathrm{Si}$ ) 
and is consistent with the conclusion that the bridging $\mathrm{V}$-O -support bond is involved in the critical kinetic steps. $\mathrm{H}$ owever, the range of TO F s is $\sim 10^{4}$ for methanol oxidation and $\sim 10^{2}$ for butane oxidation and D eN $0 x$. The lower variation of the TOFs for butane oxidation and DeNOx may reflect the additional role of acidity in the controlling kinetic steps of these reactions. In summary, the oxidation of butane to maleic anhydride depends on both the redox properties and acidic character of the bridging $\mathrm{V}-\mathrm{O}$-support bond.

\section{CONCLUSION}

In the present study the supported vanadia catalysts possessing the molecular structures reliably established by $R$ aman spectroscopy were employed in selective oxidation of $n$-butane. The results of the present study demonstrate that the nature of the metal oxide support plays a crucial role in defining catalytic properties of vanadia monolayers in n-butane oxidation to maleic anhydride. The butane oxidation TOF varied by $\sim 100$ on changing the specific oxide support. No evidence to suggest that the reducibility and the average oxidation state of vanadium affect the catalytic behavior has been found. The in situ R aman experiments also demonstrated that the characteristics of the terminal vanadyl oxygen do not correlate with the n-butane oxidation TO F s and suggest the critical involvement of the bridging $\mathrm{V}-\mathrm{O}$-support bond in $\mathrm{n}$-butane oxidation (most likely in the activated adsorption step).

Titania as a support resulted in favorably high activity and selectivity to maleic anhydride in accordance with previous observations (18) and was, therefore, used to study the effect of vanadia coverage on catalytic performance. This study indicated that the specific activity per surface vanadia species remained essentially unchanged with vanadia coverage until some microcrystalline vanadia detected in the catalysts at high coverages resulted in reduced specific activity. The results of this study also suggested that isolated surface vanadate species are capable of butane oxidation to maleic anhydride, although this oxidation was more efficient when multiple vanadate sites were present at higher coverages (two- to threefold increase in maleic anhydride TOF). This correlation probably reflects the activated adsorption of butane, since the complete reaction is very complicated. M icrocrystalline vanadia wasfound to be detrimental for the process of maleic anhydride formation. The negative effect of supported microcrystalline oxides was also observed in the case of tungsten oxide promoter.

The selectivity of the supported catalysts to maleic anhydride correlated with the L ewis acid strength of the metal oxide promoters. E specially high selectivity to maleic anhydride was found when the $V-O-P$ bonds formed after addition of phosphorus oxide in accordance with previous observations $(17,18)$. These findings indicate that the sup- ported vanadia catalysts represent a suitable model system capable of providing insights into the mechanism of n-butane oxidation on bulk VPO catalysts. The results of this work also demonstrate that the goal of preparing the active and selective supported catalysts for n-butane oxidation to maleic anhydride can be achieved by varying the properties of the metal oxide support.

\section{ACK NOWLE DG MENTS}

The work at Lehigh U niversity was supported by the Division of Basic E nergy Sciences, Department of Energy under Grant DEFG 0293E R 14350. V.V.G., J.B.B., and S.S. wish to thank the A M O CO Chemical Corporation and National Science Foundation (G rant CTS-9100130) for support. B.M.W. acknowledges the "Belgisch Nationaal Fonds voor Wetenschappelijk O nderzoek" for a travel grant.

\section{REFERENCES}

1. (a) Catal. Today 16, 1 (1993) [Proceedings, Vanadyl Pyrophosphate Catalysts (G. Centi, Ed.), Elsevier, A msterdam] and references therein; (b) Guliants, V. V., B enziger, J. B., Sundaresan, S., Y ao, N., and Wachs, I. E., Catal. L ett. 32, 379 (1995); (c) Sananes, M. T., Hutchings, G. J., and Volta, J. C., J. Catal. 154, 253 (1995); Kiely, C. J., Sajip, S., E llison, I. J., Sananes, M. T., H utchings, G. J., and Volta, J. C., C atal. L ett. 33, 357 (1995).

2. B ordes, E ., Catal. Today 1, 499 (1987), and references therein.

3. B ergeret, G., D avid, M., B royer, J. P., Volta, J. C., and H ecquet, G., Catal. Today 1, 37 (1987), and references therein.

4. H arrouch B atis, N., B atis, H., G horbel, A ., Vedrine, J. C., and Volta, J. C., J. Catal. 128, 248 (1991).

5. Sananes, M. T., Tuel, A ., and Volta, J. C., J. Catal. 145, 251 (1994).

6. Centi, G., Trifirò, F., E bner, J. R ., and Franchetti, V. M., Chem. Rev. 88, 55 (1988), and references therein.

7. Catal. Today 1, 2 (1987) [Proceedings, 1st Symposium on New Developments in Selective Oxidation (P. P. R uiz and B. Delmon, E ds.), E Isevier, A msterdam] and references therein.

8. Cavani, F., and Trifirò, F., Catalysis 11, 246 (1994), and references therein.

9. A gaskar, P. A ., D eC aul, L., and G rasselli, R. K., Catal. L ett. 23, 339 (1994).

10. Schiøtt, B., and J ørgensen, K. A ., Catal. Today 16, 79 (1993), and references therein.

11. Pepera, M . A ., Callahan, J. L., D esmond, M . J., M ilberger, E. C., Blum, P. R., and B remer, N. J., J. A m. Chem. Soc. 107, 4883 (1985).

12. (a) Wachs, I. E., D eo, G., Vuurman, M. A ., H u, H., K im, D. S., and Jehng, J.-M ., J. M ol. Catal. 82, 443 (1993); (b) Wachs, I. E., D eo, G., Vuurman, M . A ., H u, H ., K im, D. S., and J ehng, J.-M ., in "Proceedings, 10th International Congress on Catalysis, B udapest, 1992" (L. G uczi, F. Solymosi and P. Tetenyi, E ds.), p. 543, A kadémiai K iadó, B udapest, 1993.

13. Deo, G., Wachs, I. E., and Haber, J., Critical Rev. Surf. Chem. 4, 141 (1994).

14. O wens, L., and Kung, H. H ., J. Catal. 144, 202 (1993).

15. M ori, K., M iyamoto, A ., and M urakami, Y., J. Phys. Chem. 89, 4265 (1985).

16. B usca, G., Centi, G., and Trifirò, F., A ppl. Catal. 25, 265 (1986).

17. (a) N akamura, M ., K awai, K ., and Fujiwara, Y ., J. C atal. 34, 345 (1974); (b) Z azhigalov, V. A ., Z aitsev, Y. P., B elousov, V. M ., Parlitz, B., H anke, W., and Ö hlman, G., React. K inet. Catal. L ett. 32, 209 (1989); (c) R amstetter, A ., and B aerns, M., J. Catal. 109, 303 (1988); (d) Varma, R. L., and Saraf, D. N., Ind. Chem. Eng. 20, 42 (1978); (e) Kuo, P. S., and Yang, B. L., J. Catal. 117, 301 (1989); (f) Martinez-Lara, M., 
M oreno-R eal, L., Pozas-Tormo, R ., J imenez-L opez, A ., B ruque, S., Ruiz, P., and Poncelet, G., Can. J. Chem. 70, 5 (1992); (g) Derewinski, M., H aber, J., Kozlowski, R., Zazhigalov, V. A., Zajtsev, J. P., B acherikowa, I. W., and B elousov, W. M ., B ull. Polish A cad. Sci. Chem. 39, 403 (1991).

18. R uitenbeek, M ., O verbeek, R . A ., van Dillen, A . J., Koningsberger, D. C., and G eus, J. W., Recl. Trav. Chim. Pays-B as 115, 519 (1996).

19. Z azhigalov, V. A ., H aber, J., Stoch, J., B acherikova, I. V., Komashko, G. A ., and Pyatnitskaya, A . I., A ppl. Catal. A 134, 225 (1996).

20. Vuurman, M. A ., H irt, A . M ., and Wachs, I. E ., J. P hys. Chem. 95, 9928 (1991).

21. D eo, G., and Wachs, I. E ., J. Catal. 146, 335 (1994).

22. Das, N., Eckert, H., Hu, H., Wachs, I. E., Walzer, J., and Feher, F., J. Phys. Chem. 97, 8240 (1993).

23. Deo, G., and Wachs, I. E ., unpublished manuscript.

24. Jehng, J.-M., D eo, G., Weckhuysen, B. M., and Wachs, I. E., J. M ol. Catal. A : Chemical 110, 41 (1996).

25. H ardcastle, F. D., and Wachs, I. E ., unpublished manuscript.

26. (a) Chan, S. S., Wachs, I. E ., M urrell, L . L., Wang, L ., and H all, W. K ., J . Phys. Chem. 88, 5831 (1984); (b) Went, G., O yama, T., and B ell, A . T., J. Phys. Chem. 94, 4240 (1990); (c) Vuurman, M. A ., and Wachs, I. E., J. Phys. Chem. 96, 5008 (1992).

27. G. Ramis, G., C. Cristiani, C., Forzatti, P., and B usca, G., J. Catal. 116, 574 (1990).

28. (a) E ckert, H., and Wachs, I. E ., J. Phys. Chem. 93, 6796 (1989); (b) Tanaka, T., Y amashita, H., T suchitani, R ., Funabiki, T., and Y oshida, S., J. Chem. Soc. Faraday Trans. 1 84, 2987 (1988); (c) Yoshida, S., Tanaka, T., H anada, T., H iraiwa, T., and K anai, H ., Catal. L ett. 12, 277 (1992).
29. D eo, G., and Wachs, I. E., J. Phys. Chem. 95, 5889 (1991).

30. H ardcastle, F. D., and Wachs, I. E ., J. P hys. Chem. 95, 5031 (1991).

31. O wens, L., and Kung, H. H., J. Catal. 144, 202 (1993).

32. Parr, R. G., and $Y$ ang, W., "D ensity-Functional Theory of $A$ toms and M olecules," Chapters 5 and 10, Oxford U niv. Press, N ew York, 1989.

33. Pearson, R. G., Inorg. Chem. 27, 734 (1988).

34. Pearson, R. G., J. A m. Chem. Soc. 85, 3533 (1963).

35. Pauling, L., "The Chemical Bond," Cornell U niv. Press, I thaca, NY, 1967.

36. Sanderson, R. T., "Polar Covalence," A cademic Press, N ew York, 1983.

37. D atka, J., Turek, A. M ., J ehng, J.-M ., and Wachs, I. E., J. Catal. 135, 186 (1992).

38. (a) Conatkes, S., and Wachs, I. E., unpublished manuscripts (b) Kalakkad, D., Datye, A. K., and Robota, H., A ppl. Catal. B 1, 191 (1992).

39. Wachs, I. E ., Saleh, R. Y., Chan, S. S., and Chersich, C. C., A ppl. Catal. 15, 339 (1985).

40. (a) M iyata, H ., Fujii, K ., and O no, T., J. Chem. Soc. Faraday Trans. 84, 3121 (1988); (b) Turek, A . M., Wachs, I. E ., and D eCanio, E., J. Phys. Chem. 96, 5000 (1992).

41. Wachs, I. E ., D eo, G., A ndreini, A ., Vuurman, M . A ., de B oer, M ., and A miridis, M., J. Catal. 161, 211 (1996).

42. R amis, G., B usca, G., and L orenzelli, V., in "Structure and R eactivity of Surface," (C. M orterra, A . Z ecchina, and G. Costa, E ds.), E Isevier, A msterdam, 1989.

43. G ai, P. L., and Kourtakis, K., Science 267, 661 (1995).

44. D eo, G., and Wachs, I. E., J. Catal. 146, 323 (1994).

45. Topsoe, N. Y., Topsoe, H ., and D umesic, J. A ., J. Catal. 151, 226 (1995). 